\title{
sciendo
}

\section{THE POTENTIAL EFFECT OF DIETARY TANNINS ON ENTERIC METHANE EMISSION AND RUMINANT PRODUCTION, AS AN ALTERNATIVE TO ANTIBIOTIC FEED ADDITIVES - A REVIEW}

\author{
Aamir Nawab ${ }^{1}$, Guanghui $\mathrm{Li}^{1}$, Lilong An ${ }^{1 \star}$, Yasir Nawab ${ }^{2}$, Yi Zhao ${ }^{1}, \mathrm{Mei}_{\mathrm{Xiao}}{ }^{1}$, Shuyan Tang ${ }^{1}$ \\ Chenyu Sun ${ }^{1}$ \\ ${ }^{1}$ Department of Animal Science, Agricultural College, Guangdong Ocean University, \\ Zhanjiang 524088, Guangdong, China \\ ${ }^{2}$ Faculty of Veterinary Medicine, PMAS-Arid Agriculture University Rawalpindi, Pakistan \\ •Corresponding author: anlilong@126.com
}

\begin{abstract}
Antibiotic growth promoters in livestock nutrition cause microbial resistance which produces threats to human health. Therefore, tannins have been considered as natural alternative antibiotic feed additives which possess various biological properties including antimicrobial, anti-inflammatory, antioxidant and immunomodulatory. Additionally, these plants also have antiparasitic and anti-bloat characteristics which contribute to inhibit the enteric methane emission in order to improve nutrient digestibility, milk and meat quality, fatty acids composition and ruminant production. Antibiotic growth promoters have been practiced in animals feeding to increase feed intake, growth rate, weight gain as well as reduce metabolic disorders and energy losses in the rumen. In 2006, the European Union banned the usage of antibiotic growth promoters in the feeding of livestock. This antibiotic resistance issue has increased demand to explore the natural feed additives that might be useful for animal production system. Consequently, natural forages have been categorized as potential feed additives in animal production since it improves nutritive value, protein digestibility, increase amino acid absorption and growth rate. But, some plant materials are usually rich in tannins known as anti-nutritional factors. Therefore, the application of tanninrich plants in ruminant nutrition needs great precaution due to its possible injurious effects (dose dependent) on animal health such as metabolic disorders. Hence, there is need to give attention to the usage of tannins in ruminant nutrition as an alternative to antibiotics feed additives to investigate its effects on enteric methane emissions and ruminants production. In addition, safety and risk associated with tannins feeding have also been briefly discussed.
\end{abstract}

Key words: condensed tannins, hydrolysable tannins, feed additives, methane emission, ruminants

The world human population is increasing and it is estimated to be 9.15 billion by 2050 (Gemeda and Hassen, 2018). This might increase the demand at consumer level for organic livestock products such as milk and meat (Bunglavan and Dutta, 2013). 
Regarding the above increasing population issue, the animal products consumption rate is still lower in developing countries as compared to developed countries, indicating significant need to enhance livestock production (Thornton and Gerber, 2010; Gemeda and Hassen, 2018). Antibiotic growth promoters in ruminant nutrition have been used for several years to increase the productive efficiency. However, it has been reported that antibiotic growth promoters used for long time cause microbial resistance in animals (Chattopadhyay et al., 2014). Therefore, researchers have worked to find natural alternatives to feed additives to reduce threats of drug resistance in human health.

Local plants containing tannins have been considered as potential feed additives for ruminants (Yang et al., 2015). These plants are very essential in animal feeding due to their high protein profile that is available in dry and hot season when forage resources are unavailable (Koneswaran and Nierenberg, 2008). Therefore, the Food and Agriculture Organization (FAO, 2013) has declared that there is strict need to utilize local resources in the feeding of animals to avoid the fodder scarcity in future. Browse species are usually rich in plant phenolic substances generally known as tannins (Makkar, 2003; Lee et al., 2010). Tannins are naturally growing plant secondary compounds with different molecular weight and these are present in almost all vascular plants usually fed by ruminants (Table 1) (Wang et al., 2015).

Table 1. Chemical nature of tannic acid

\begin{tabular}{ll}
\hline \multicolumn{1}{c}{ Name } & \multicolumn{1}{c}{ Tannins } \\
\hline Types & Condensed tannins and hydrolysable tannins \\
CAS number & $1401-55-4$ \\
Molecular formula & $\mathrm{C}_{76} \mathrm{H}_{52} \mathrm{O}_{46}$ \\
Molecular weight & $1701.206 \mathrm{~g} / \mathrm{mol}$ \\
Solubility in water & $2850 \mathrm{~g} / \mathrm{L}$ \\
Color & Light yellow to tan solid \\
Melting point & Decomposes above $200^{\circ} \mathrm{C}$ \\
Flash point & $390^{\circ} \mathrm{F}$ \\
Acidity (PKa) & $\mathrm{Ca} .10$ \\
\hline
\end{tabular}

Tannins have both beneficial and deleterious effects depending on its composition, concentration, animal species and physiological status (Patra and Saxena, 2011). Tannins are divided into hydrolysable (HT) and condensed tannins (CT) (Figure 1). Specifically, tannins have significant anti-bloat characteristics that makes proteins unavailable for rumen degradation and reduces urine $\mathrm{N}$ excretion, intestinal parasites and enteric methane emission (greenhouse gas) which, in turn, can improve the milk production, wool growth, reproductive efficiency and immune responses (Min and Hart, 2003; Ramírez-Restrepo and Barry, 2005; Waghorn, 2008; Aufrere et al., 2013; Attia et al., 2016). CT containing feed has potential effects on livestock performance (Gxasheka et al., 2015) by reducing gut parasite (Krueger et al., 2010). A study has reported that steers fed tannins based Acacia karroo, had improved weight gain (WG), body condition score (BCS) and carcass weight (CW) as compared to control 
group (Mapiye et al., 2011). Mostly, methane gas is contributed from the agriculture sector, especially from livestock. A scientific study has recorded that cattle and sheep produce methane in amounts of about 250-500 and 20-55 1/day depending on dry matter intake (DMI), respectively (Eckard et al., 2010). This not only affects the energy utilization of ruminants, but also contributes to environmental pollution (Eckard et al., 2010). Hence, the purpose of this current review was to provide the scientific insights into the use of dietary tannins to reduce enteric $\mathrm{CH}_{4}$ emission which, in turn, might minimize the effect of global warming and improve ruminant production.

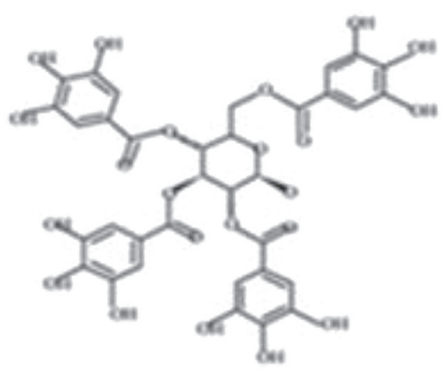

Hydrolysable tannin

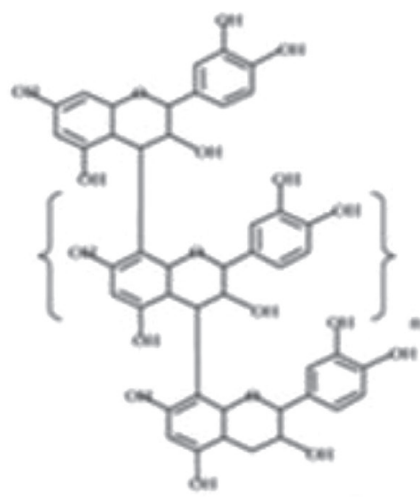

Condensed tannin

Figure 1. Chemical structure of hydrolysable and condensed tannin

\section{Local forages as feed additives}

Several countries face the problem of fodder scarcity for livestock especially during winter season (dry season) (Gxasheka et al., 2015). Therefore, tannins containing feedstuff and crop byproduct supplementation is a common practice in rural regions of several countries including Pakistan, China and South Africa (Gxasheka et al., 2015). Generally, corn stock is a commonly fed supplement during the time of fodder scarcity (Beyene et al., 2014). Trees and bushes present in hot climatic regions are efficient feed resources for livestock (Belachew et al., 2013). But, small scale farmers use these feedstuff with poor quality fodder as feed additives to increase the palatability of feed due to its high protein content which is easily available and provides green roughages to ruminants (Yisehak et al., 2012). Some studies have used acacia species (A. karroo, A. nilotica, A. tortilis, A. galpinii, A. sieberiana, A. hebeclada and A. rhemniana) as feed supplement in farm animals (Table 2) (Ngambu et al., 2013).

All acacia species contain more than $100 \mathrm{~g} / \mathrm{kg}$ DM of crude protein which is suitable to fulfill the requirements for ruminants (Jamala et al., 2013). A study observed that goat fed A. karroo had improved growth rate (Ngambu et al., 2013). These plant species increase feed palatability that are highly efficient for farm animals and provide good quality carcasses (Arsenos et al., 2009; Mapiye et al., 2009). However, now there is need to efficiently manage these resources without exhausting them. 
Table 2. Tannins \% in plant parts of Acacia species

\begin{tabular}{l|c|c|c|c}
\hline \multicolumn{1}{c|}{ Species } & $\begin{array}{c}\text { \% Phenolics in plant } \\
\text { part before } \\
\text { precipitation }\end{array}$ & $\begin{array}{c}\text { Phenolics in plant } \\
\text { part after } \\
\text { precipitation }\end{array}$ & $\begin{array}{c}\text { Tannins in plant } \\
\text { part } \\
\text { (hide-powder) }\end{array}$ & References \\
\hline $\begin{array}{l}\text { Acacia nilotica } \\
\text { (Leaf) }\end{array}$ & 14.00 & 2.20 & 11.80 & Eldin et al. (2014) \\
$\begin{array}{l}\text { Acacia seyal (Leaf) } \\
\begin{array}{l}\text { Acacia nilotica } \\
\text { (Bark) }\end{array}\end{array} \quad 11.00$ & 0.69 & 6.31 & \\
$\begin{array}{l}\text { Acacia seyal (Bark) } \\
\text { Acacia Senegal } \\
\text { (Bark) }\end{array}$ & 12.75 & 0.53 & 10.47 & \\
$\begin{array}{l}\text { Acacia nilotica } \\
\text { (Mature fruit) }\end{array}$ & 4.25 & 0.60 & 12.15 & \\
$\begin{array}{l}\text { Acacia nilotica } \\
\text { (Immature fruit) }\end{array}$ & 24.75 & 0.76 & 3.49 & \\
\hline
\end{tabular}

Total phenolic concentration comparative to tannic acid (TA).

\section{Tannins adaptation}

Adaptation to tannins depends on animal breeding which show various responses to tannins feeding (Papanastasis et al., 2008). Mainly, cattle and sheep ingest tannins free fodder; they do not need to produce tannin-binding salivary proteins (TBSP) (Lamy et al., 2011), because CT adaptation plays a defense mechanism in ruminants, like extracellular excretions decrease the effect of tannins on bacteria, rather than tannin degradation (Mlambo et al., 2007). Therefore, feed intake is influenced by adaptation period, primarily during first 6 days or during 6 to 24 days (Salem et al., 2005).

\section{Effects of tannins on animal production}

Plants that contain CT have been identified as alternative resources in ruminant nutrition (Figure 2) (Min et al., 2006; Bhattarai et al., 2016; Naumann et al., 2017). Numerous tannins containing feedstuff have various effects on animals body depending on their composition, concentration dosage and intake (Huang et al., 2017). A study reported that sheep consuming a CT (H. coronarium) diet had increased body weight compared to those consuming lucerne or perennial pasture (Iqbal et al., 2002). L. corniculatus given to sheep had improved production performance as compared to control group consuming fodder treated with polyethylene glycol (PEG) (Frutos et al., 2004). In addition, voluntary feed intake and animal production is also influenced by type of CT present in feeds. A study in lambs has revealed that growth rate was reduced from $140 \mathrm{~g}$ to less than $50 \mathrm{~g} /$ day by supplementation of $26 \mathrm{~g} / \mathrm{kg}$ CT containing Ceratonia siliqua (carob pulp) (Priolo et al., 2000). Moreover, sheep given CT from L. pedunculatus had decreased carcass to fat proportion as compared to lucerne diet without CT. But, CT from H. coronarium (white garland-lily) $72 \mathrm{~g} / \mathrm{kg}$ of DM showed no deleterious effect on lambs weight gain (WG) (Douglas et al., 1999; Piluzza et al., 2013). Besides, the live weight gain of male lambs was increased by supplementation of $37.5 \mathrm{mg} / \mathrm{kg} \mathrm{CT}$ containing leaves of $L$. acapulcensis 
(García-Hernández et al., 2017). These variations in consequences depend on the animal's health, environment and housing as well as tannin concentration, composition, and structural diversity.

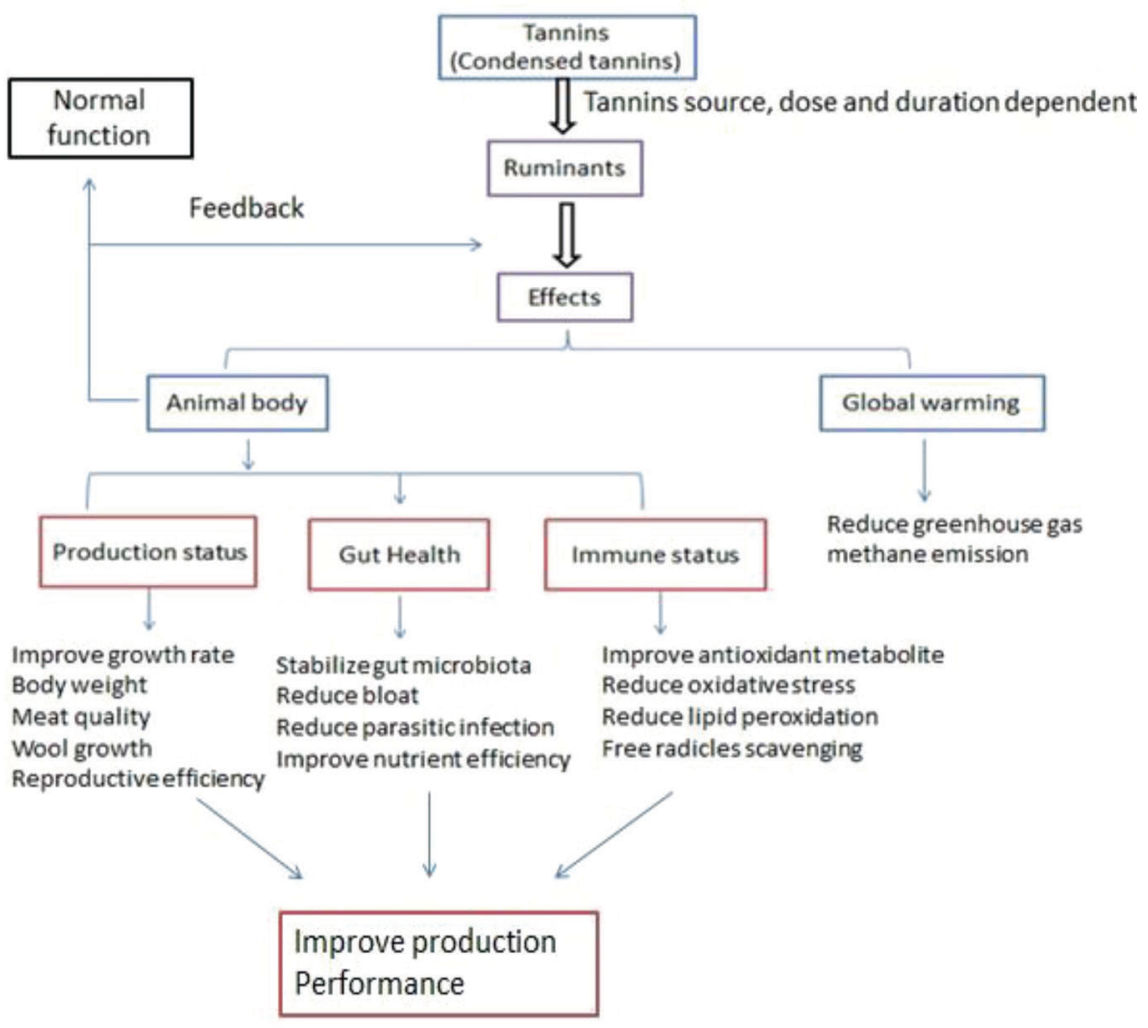

Figure 2. Effect of tannins on ruminant animal production (Carulla et al., 2005)

A feeding experiment has indicated that goats fed CT plants and Mediterranean shrubs (Mirtus communis, Pistacia lentiscus, Quercus ilex, Arbutus unedo etc.) had increased conjugated linoleic acid (CLA) and trans-vaccenic acid milk fat contents as compared to those animals grazed without CT feed (Vasta et al., 2008). However, some compounds other than CT can be involved in CLA production when Mediterranean shrubs were consumed by dairy sheep and goats. Another study has shown that lambs given Hedysarum coronarium L. (sulla) had no significant effects on meat CLA and trans-vaccenic acid contents (Priolo et al., 2005). It has proposed that Hedysarum coronarium L. (sulla) containing $18 \mathrm{~g} \mathrm{CT} / \mathrm{kg}$ DM diet was not sufficient to fulfill the requirements of ruminal bacteria responsible for biohydration of linoleic and linolenic acids (Priolo et al., 2005).

Moreover, lambs given 100 and $200 \mathrm{~g} / \mathrm{kg}$ DM Cistus ladanife (grape seed extract) had improved color of fresh meat during prolonged refrigerated storage; this results was due to positive effects of dietary tannins on concentration of haem pig- 
ment and formation of metmyoglobin during storage condition (Francisco et al., 2015). But, the phenomenon in which tannins can affect myoglobin concentration is unclear. Several authors have described that it may be due to structural diversity of tannins (Table 3) (Gómez et al., 2006; Jayanegara et al., 2011; Soltan et al., 2012). Hence, tannin plants need to be given consideration because their composition, properties and chemical reactivity have significant differences and thus there is need for better understanding the conflicting results achieved by CT containing plant resources.

Table 3. Chemical composition of tannins containing plant species ( $\%$ age)

\begin{tabular}{l|c|c|c|c|c|l}
\hline \multicolumn{1}{c|}{ Species } & TP & CT & CP & NDF & ADF & \multicolumn{1}{c}{ References } \\
\hline Lespedeza cuneata & - & 20.0 & 10.3 & 40.1 & 39.9 & Puchala et al. (2005) \\
Guazuma ulmifolia & 2.8 & 4.7 & 10.4 & 42.5 & 29.5 & Gómez et al. (2006) \\
Acacia farneziana & 10.0 & 4.5 & 24.0 & 42.1 & 26.7 & Gómez et al. (2006) \\
Swietenia mahagoni & 20.7 & 8.6 & 11.2 & 28.1 & 22.2 & Jayanegara et al. (2011) \\
Myristica fragans & 18.1 & 7.2 & 10.1 & 38.0 & 36.1 & Jayanegara et al. (2011) \\
Prosopis juliflora & 2.9 & 0.04 & 17.9 & 49.4 & 38.4 & Soltan et al. (2012) \\
Acacia saligna & 9.1 & 6.3 & 13.8 & 46.5 & 42.8 & Soltan et al. (2012) \\
Leucaena leucocephala & 5.17 & 2.3 & 23.6 & 78.9 & 51.1 & Soltan et al. (2013) \\
\hline
\end{tabular}

\section{Effects of tannins on nutritive value of forage legumes}

Forages that contain tannins are beneficial and some can be detrimental to animals health (dose dependent) (Dey and Sarathi De, 2014). For example, high concentrations of tannins can reduce feed intake, carbohydrates metabolism and protein digestibility which can ultimately cause the loss of production.

Several authors suggest that tannins concentration of 20 to $40 \mathrm{~g} / \mathrm{kg}$ is considered beneficial in small ruminants (Frutos et al., 2004). A study has observed that CT concentrations less than $50 \mathrm{~g} / \mathrm{kg}$ DM were nutritious for ruminants without reducing feed intake and fiber digestion (Min et al., 2003; Yuxi et al., 2015). Whereas high amounts of CT, more than $50 \mathrm{~g} / \mathrm{kg}$, were harmful for ruminants which decreased feed intake and protein digestibility (Frutos et al., 2004). Tannins have different affinity for proteins and amino acids. For example, some herbivores adapt tanniferous feed by producing proline-rich protein saliva (Mole et al., 2015). Normally, CT form complexes with proteins that are not degraded over the $\mathrm{pH}$ range of 3.5-7.0, but dissociate at $\mathrm{pH}$ below 3.5 in the abomasum and anterior duodenum (Alipour and Rouzbehan, 2010; Mokni et al., 2017). These CT-protein complexes remain undegradable in the rumen and more amino acids are absorbed postruminally (Min et al., 2003; Soltan et al., 2012; Huang et al., 2017).

A study in Yucatán (Mexico) has indicated that ruminants given CT based L. leucocephala in a concentration of $46 \mathrm{~g}$-eq of tannic acid $/ \mathrm{kg}$ DM had reduced rumen degradable protein from 614 to $117 \mathrm{~g} / \mathrm{kg}$ of DM and rumen undegradable protein (RUP) was increased from 386 to $888 \mathrm{~g} / \mathrm{kg}$ DM as compared to a grass without tannins (Pineiro-Vázquez et al., 2015). It was reported that increase in RUP from 416 to $464 \mathrm{~g} / \mathrm{kg}$ DM was due to increased excretion of fecal nitrogen. Soltan et al. (2013) 
demonstrated that feed containing 8.8 g-eq TA/kg DM had increased fecal nitrogen by $70.19 \%$ and decreased nitrogen excretion in urine by $12.9 \%$ (Soltan et al., 2013). In addition, steers fed $2.4 \%$ CT based sainfoin had reduced protein digestibility by 7\% (Brinkhaus et al., 2017).

Various studies suggest that carob (Ceratonia siliqua) containing $25 \mathrm{~g} / \mathrm{kg} \mathrm{CT}$ can be harmful (dose and plants species dependent), but sainfoin containing $80 \mathrm{~g} / \mathrm{kg}$ CT had beneficial consequences (Mueller-Harvey, 2006). Various feeding trials have reported that CT concentrations less than $50 \mathrm{~g} / \mathrm{kg}$ are beneficial for only Lotus species and it can be deleterious to other plants. Schofield et al. (2001) and Huang et al. (2011) have revealed that CT affinity for protein can be different dependent on the plant resources (Huang et al., 2011; Schofield et al., 2001). This shows that most CT-protein complexes may not fully degrade post-ruminally. Therefore, certain CT plants cannot enhance the supply of digestible protein. In vivo study has indicated that sheep fed CT extract from Acacia aneura (mulga, native forage tree of Australia) and Leucaena pallida (guaja, native forage tree of Mexico) diet had no visible effect on protein digestibility (Andrabi et al., 2005). Normally, high protein digestibility was observed which indicates the complete detachment of the tannin-protein complexes. However, CT containing L. corniculatus given to small ruminants had reduced degradation of plant methionine and cysteine in the small intestine of sheep. The proportion of digestion was less in the proximal part and was higher in the distal part of the small intestine (McNabb et al., 1993; Bunglavan and Dutta, 2013; Pathak et al., 2017). A similar study has reported that ruminants supplemented with CT containing Lotus corniculatus (birdsfoot trefoil) and Hedysarum coronarium (sulla) had increased the absorption of essential amino acid (EAA) in the small intestine, however these outcomes were not observed in L. pedunculatus (big trefoil) and Onobtychis viclifolia (sainfoin) due to structural differences of CT (Min et al., 2003).

\section{Effects of tannins on rumen microbiota}

Tannins have different effects on rumen microbiota due to its diverse concentration and composition (Patra and Saxena, 2011). A study has indicated that sheep supplemented with perennial ryegrass (Lolium perenne), white clover (Trifolium repens) and L. corniculatus (32 g CT/kg DM), had decreased the population of proteolytic rumen bacteria (Clostridium proteoclasticum, Eubacterium sp., Streptococcus bovis and Butyrivibrio fibrisolvens) (Min et al., 2006). Tannins acceptance for microorganism depend upon the species and properties of tannin (Petek and Dikmen, 2006). Some in vitro studies investigated the growth and proteolytic activity of eleven ruminal samples and they suggested that steers fed L. corniculatus containing CT diet had transiently increased the growth of some ruminal bacteria (C. proteoclasticum and Ruminococcus albus) at lower concentration $(50-100 \mu \mathrm{g} / \mathrm{mL})$ but no effects were observed at higher concentrations of CT (more than $200 \mu \mathrm{g} / \mathrm{mL}$ ), whereas nine strains of ruminal bacteria were more susceptible to CT at low concentrations (Min et al., 2005; Bunglavan and Dutta, 2013; Jonker and Yu, 2017). 


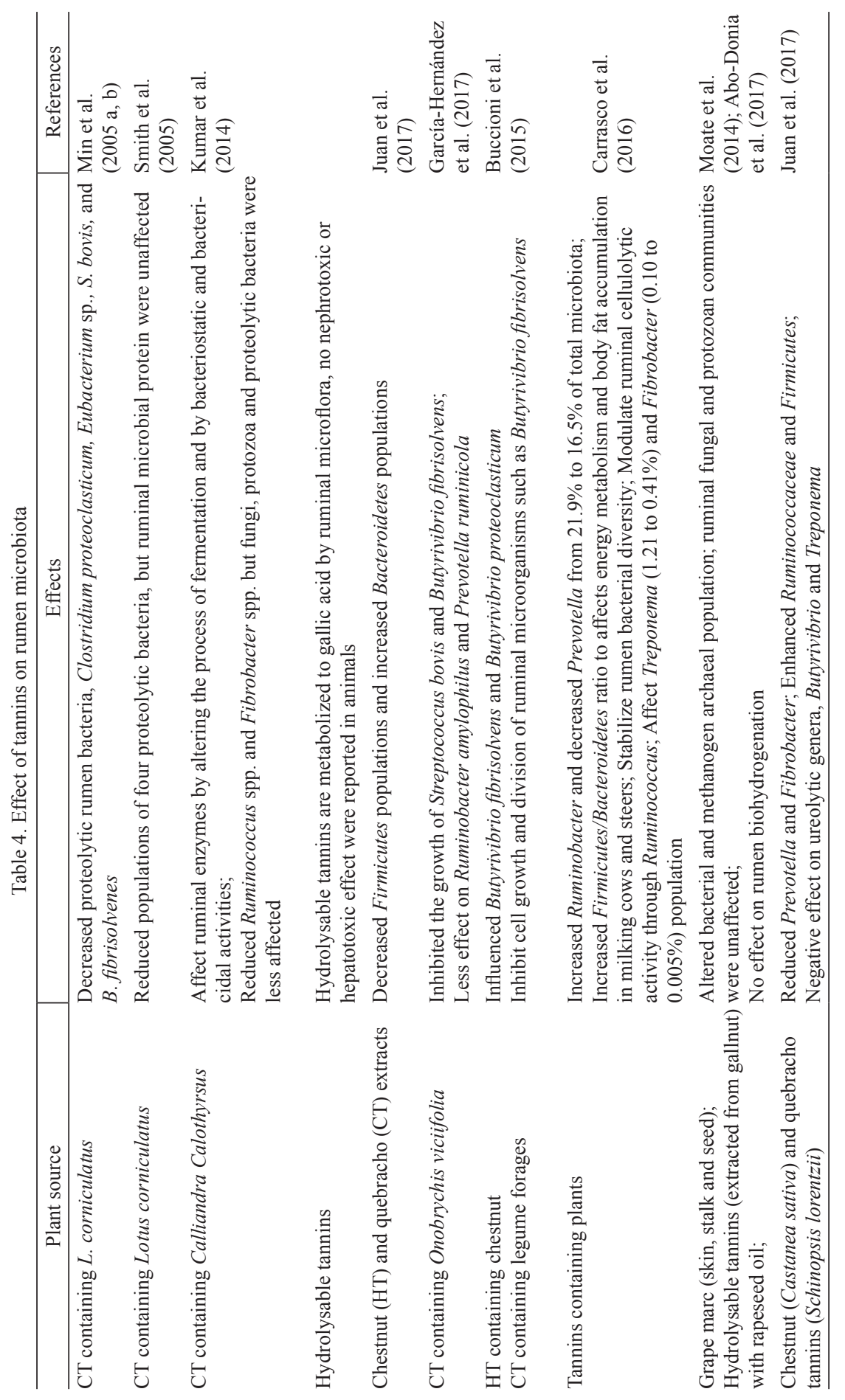




\section{Effects of tannins on ruminant species}

Tannins-containing diet improves the efficiency of protein digestion, especially rumen escape protein and increases daily weight gain (DWG) (Barry and Mcnabb, 1999; Min et al., 2003). Min et al. (2003 and 2005) described that steers consuming wheat forage with addition of $1.5 \% \mathrm{CT}$ (quebracho) increased average daily gain (ADG) by 15\% (Min et al., 2003 and 2005) and cattle consuming wheat forage and plant tannins had improved body weight gain due to modification of rumen metabolites and microbial populations (Table 4) (Min et al., 2003 and 2005). Generally, sheep consuming CT-containing diets reduced proteolysis of high quality forage, but increased rumen by-pass protein (Min et al., 2003). A study observed that feedlot heifers given corn and CT supplemented feed had increased feed intake, average daily gain and total weight gain (Rivera-Mendez et al., 2016).

Tannins have potential to increase protein supply and reduce parasitic infection in domestic animals. Hervás et al. (2003) found that in sheep, CT extract diet (quebracho) fed at less than $1.5 \mathrm{~g} / \mathrm{kg} \mathrm{LW}$ (live weight) or less than $83 \mathrm{~g} / \mathrm{kg} \mathrm{DM} /$ day was not toxic for digestive tract and plasma profile (Hervás et al., 2003). However, feeding sheep CT up to $3 \mathrm{~g} / \mathrm{kg} \mathrm{LW}$ or $188 \mathrm{~g} / \mathrm{kg} / \mathrm{DM} /$ day was harmful for plasma metabolites and digestive track (lesions) (Hervás et al., 2003). Plasma urea concentration was suppressed in dairy cows by consumption of mimosa tannins $(3.5 \mathrm{~g} / \mathrm{kg} \mathrm{DM})$ but no negative effects appeared in milk production (Min et al., 2015). On the other side, no negative effect was observed in lambs by consumption of HT containing chestnut tannins (20.8 g/kg/daily DM) or (15-25 kg LW) (Petek and Dikmen, 2006). A similar study has revealed that heifers had increased $\mathrm{ADG}$ about $8 \%$ to $19 \%$ by addition of mimosa and chestnut tannins diet respectively, and no detrimental effect were observed on esophagus and blood profile. The ADG was increased due to reduction of parasitic infections such as Cooperia and O. ostertagi fecal parasites (Min et al., 2015).

In cattle, the addition of $1.5 \%$ mimosa and chestnut tannins per $\mathrm{kg} / \mathrm{DMI}$ had no adverse effect on blood profile except plasma cholesterol level. Cattle consumed $1.5 \%$ chestnut tannins had increased plasma cholesterol level after 70 days trial, but these outcomes were not associated with mimosa tannins, indicating that HT may affect lipid metabolism by unidentified mechanisms. The above findings also indicated that feeding low level tannins (less than $1.5 \%$ tannins/DMI) to ruminants had no disadvantageous effects. Tannins protect the gut mucosa from pathogens and oxidative damage. Furthermore, tannins reduce the peristaltic movement during indigestion which subsequently prevent the incidence of diarrhea in young calf (Gai et al., 2011).

\section{Effects of tannins on intestinal absorption}

Generally, several studies mentioned that CT reduces rumen degradability of protein and enhances the availability of protein absorption in the small intestine (Iqbal et al., 2007; Getachew et al., 2008; Pathak et al., 2017). In high producing animals, low concentration of CT increases supply of essential amino acids (EAA) in the intestines without influencing the feed intake, milk let-down and feed conversion ratio (Wanapat, 2003; Soltan et al., 2012). However, the absorption of EAA was reduced at higher $\mathrm{CT}$ concentrations. The limited concentration of tannins enhance protein metabolism inside the abomasum and small intestine, and improve the absorption of 
amino acids (Min et al., 2003; Wanapat, 2003). In addition, microbial protein flow to small intestines does not decrease by tannins; thereby CT-protein complexes make protein unavailable for rumen degradation and provide protein supply to small intestine for maximum absorption (McSweeney et al., 2001; Pathak et al., 2017), which is essential for lactating cows.

\section{Effects of tannins on wool growth}

Several authors have observed that sheep consuming CT feed had increased weight and fleece growth due to $\mathrm{CT}$ effect on the absorption of sulfur containing amino acids (SAA) (Min et al., 2001; Mueller-Harvey, 2006; Bunglavan and Dutta, 2013). Protein plays a key role in clean wool production, with a high cysteine quantity but amino acids containing sulfur have detrimental effect on wool production (Reed et al., 1990). CT containing diet can increase the loss rate of cystine in the blood plasma, mainly due to reducing losses of SAA in the rumen. CT supplemented diet can increase fleece growth due to increasing the absorption of SAA and various other EAA (Waghorn, 2008; Pathak et al., 2017). However, CT from L. corniculatus had beneficial effects on wool production at 22-38 g CT/kg DM (Min et al., 2003). Whereas, CT containing sulla and L. pedunculatus had deleterious effects at $>50 \mathrm{~g} / \mathrm{kg}$ DM. On the other hand, the response of wool growth was variable when CT quantity was less than $22 \mathrm{~g} \mathrm{CT} / \mathrm{kg}$ DM. According to Priolo et al. (2000), wool growth was increased in lambs by supplemented CT extract from L. corniculatus at dose of $35 \mathrm{~g} / \mathrm{kg}$ DM. The results variation was due to differences in chemical composition, concentration and dosage of CT, which can affect the biological activity (Pathak et al., 2017).

\section{Effects of tannins on milk secretion}

Tannins have diverse effects on dairy animals. In dairy cattle, the addition of L. corniculatus had increased milk production by $60 \%$ and protein quantity by $10 \%$ compared to control group (without CT) (Table 5). Min et al. (2003) has reported that CT based L. corniculatus given to milking ewes had no effect on milk let-down in early lactation, but secretion rates of whole milk, protein and lactose were enhanced by 21,14 and 12\% during mid and late lactation, respectively (Min et al., 2003). In lactating animals, CT had increased milk quantity but there was no effect on feed intake (Min et al., 2003).

Furthermore, CT at $35 \mathrm{~g} / \mathrm{kg}$ DM purified from L. corniculatus had increased milk production in lactating ewes and wool growth in lambs without causing injurious effects on feed intake, milk protein or lactose and fat percentage (Berard et al., 2011). A study has exposed that quebracho (QT) and chestnut tannins and/or grape seeds containing dietary phenols with soybean oil supplemented to small ruminants had increased linoleic, vaccenic and rumenic acids concentration and reduced the concentration of saturated fatty acids in ewes milk (Buccioni et al., 2015). Several reports have investigated that CT had increased milk yield in small ruminants as compared to control group (Vasta et al., 2008; Salem, 2010). In goats, the milk yield/day was increased by supplementation of $20 \%$ grape seed skin extract (GSSE) after 20 days of treatments (Mokni et al., 2017). In the above study, GSSE was composed of flavonoids (25.42\%), non-flavonoids (74.57\%) and tannins (5.25\%) (Mokni et al., 2017). Specifically, grape 
seed extract (GSE) increased the milk production in dairy cows, due to modification of ruminal metabolism (Gessner et al., 2015). Dey and Sarathi De (2014) also described that dairy cows given CT had improved milk yield. Some authors explored that CT based Acacia mearnsii (bark of black wattle tree) had no effects on milk production in dairy cows (Gerlach et al., 2018 a, b). Furthermore, decreased milk yield was observed in ewes supplemented with QT, whereas acacia species consumed by ruminants had also no effects on milk production. Several other studies claim that protein protection from microbial degradation results in improved milk production in dairy cows, sheep and goats (Attia et al., 2016). These various consequences were expected due to different chemical composition, properties and chemical reactivity of tannins which in turn deviate the rumen microbial ecosystem and volatile fatty acids concentration (Minieri et al., 2014; Carreno et al., 2015).

\section{Tannins as an alternative to antibiotics growth promoters}

Antibiotic growth promoters cause microbial resistance in food animals which produce threats to human health (drug resistance). Therefore, plant secondary compounds (tannins) have been classified as an alternative to antibiotic growth promoters which might prevent diseases and enhance production in ruminants (Huang et al., 2017). Ideal antibiotic feed alternatives should have the same beneficial effects of antibiotics growth promoters (AGPs), such as positive effects on animal performance (average daily gain), antibacterial activity, antioxidant property, improvement of the nutrient availability, gut microbiota and immunity (Huang et al., 2018).

The European Medicines Agency (EMA) and the European Food Safety Authority (EFSA) have suggested that these compounds have antimicrobial and growth promoting characteristics. They have potential to promote animal growth depending on plants efficacy, dosage, composition and concentration. In cattle, some studies showed that due to lack of sufficient data it is difficult to reach a final decision regarding tannin plants as growth promoters (EFSA, 2014). But, several other studies revealed that tanniferous plants can reduce the incidence of diarrhea and improve the gut health in young calves (Hook et al., 2010). These feedstuffs are required at higher concentrations in feed (to achieve antimicrobial effects) to increase body weight gains. However, higher concentration negatively affects meat quality.

The possible mechanisms proposed to understand antimicrobial activity of tannin is due to direct action on microbial metabolism, inhibition of microbial enzymes, formation of complexes with bacterial cell membrane, deprivation of metal ions or deficiency of the substrates essential for microorganism (Liu et al., 2013). Various evidences have revealed that tannins possess antimicrobial ability due to its inhibitory action on microbial cell membrane (McAllister et al., 2005; Liu et al., 2013) through cell aggregation and/or disruption of cell membranes. However, protein precipitation is a universal property for all dietary tannins, but anti-microbial ability of tannins is microbe speciesspecific that is closely associated to the composition and chemical structure of tannins. Normally, dietary tannins have greater anti-microbial activity against Gram-positive bacteria as compared to Gram-negative bacteria (Smith and Mackie, 2004) because of an outer membrane of Gram-negative bacteria that possess a lipid bilayer structure (lipopolysaccharide and proteins) and an inner layer composed of phospholipids. 


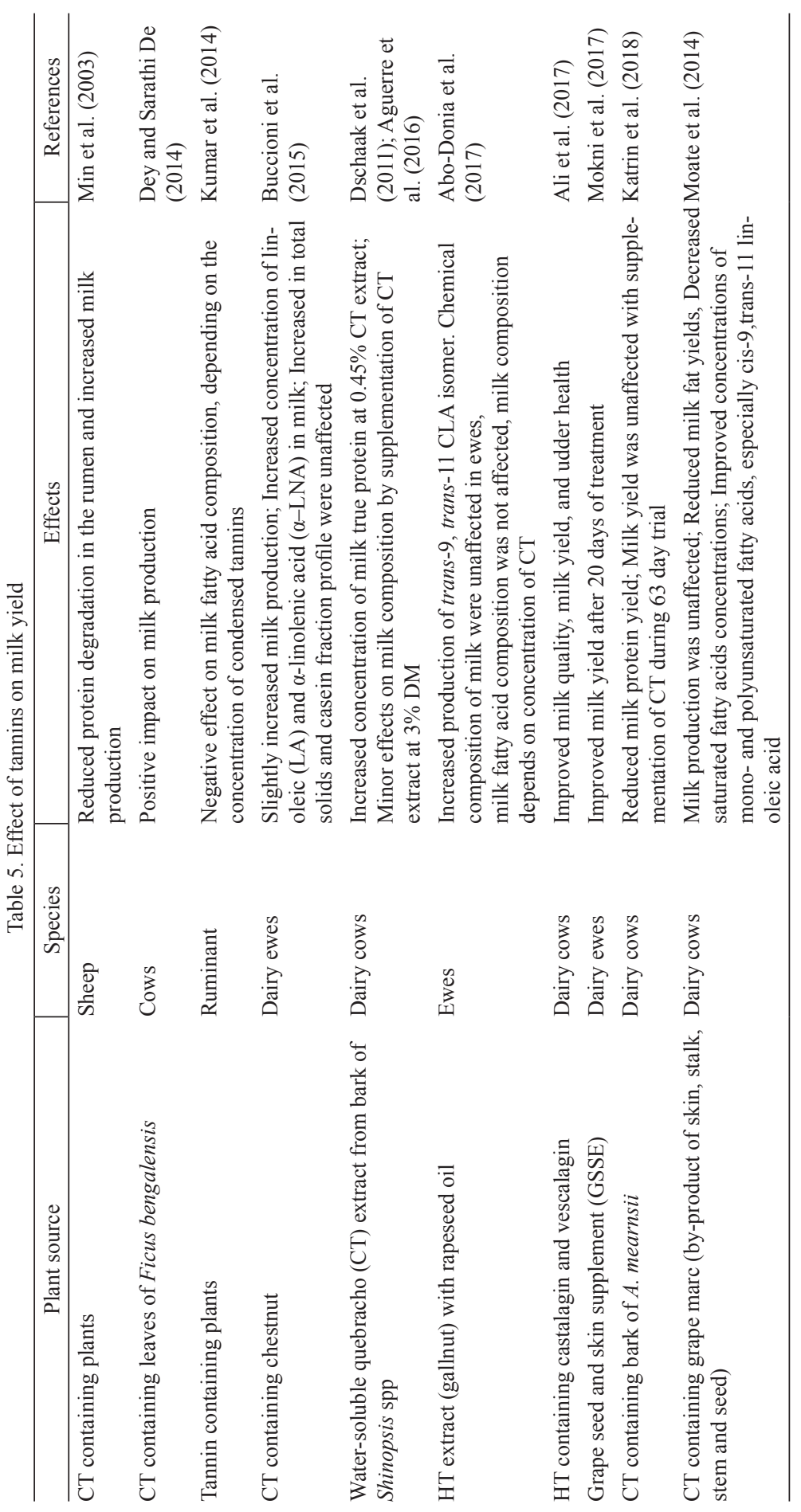




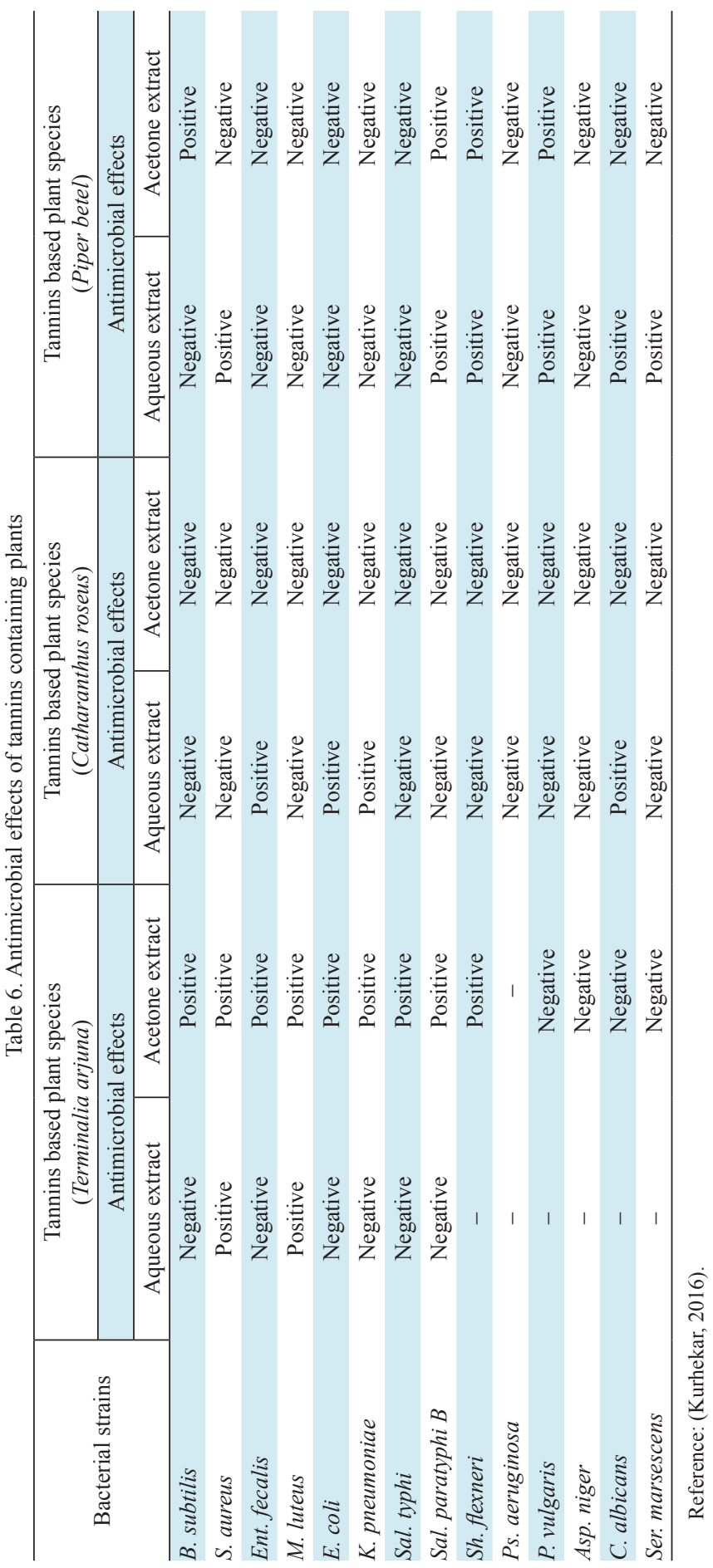


Conversely, some species of plants containing CT have strong activity against Gram-negative bacteria. Very clearly, some authors have investigated that all pathogenic bacteria including Salmonella, Escherichia coli O157:H7, Shigella, Pseudomonas, Helicobacter pylori and Staphylococcus were sensitive to tannins supplementation (Doss et al., 2009; Banso and Adeyemo, 2007; Liu et al., 2013). Wang et al. (2013) focused 12 tannins species and observed that only CT based purple prairie clover (Dalea purpurea Vent) and phlorotannins (PT) from brown algae (Ascophyllum nodosum) possessed strong anti-E. coli and anti-E. coli O157:H7 activity. Another study has exposed that PT have greater antimicrobial activity compared with CT and HT (Wang et al., 2009). It has been proposed that antimicrobial property of tannins depend on the number of hydroxyl groups and liberation of hydrogen peroxide during oxidation of tannins (Mueller-Harvey, 2006).

A similar study has found that HT extracted from Rhizophora apiculata can be used as potential agent against yeast (Lim et al., 2006). The antimicrobial properties of HT is linked with the hydrolysis of ester linkage between gallic acid, usually as multiple esters with D-glucose, which affects the synthesis of cell wall and cell membrane. Therefore, taken together, it has been concluded that screening, identification and source of tannins results in great diversity in their antimicrobial activities that can be effective and specific to target microbes depending on tannins species (Table 6).

Antiparasitic effects of tannins

CT from forages as alternatives to antiparasitic drugs provide beneficial effects (Carvalho et al., 2012). CT rich plants have beneficial effects on animal health due to its direct antiparasitic effects towards worm egg count, worm fecundity (no. of eggs) and egg hatchability (Figure 3) (Athanasiadou et al., 2001; Nguyen et al., 2005; Githiori et al., 2006; Alonso-Diaz et al., 2011; Mejia-Hernandez et al., 2014).

CT extract from sainfoin has mild anthelmintic (antiparasitic) effect on ruminant parasites (Table 7) (Heckendorn et al., 2007; Bhattarai et al., 2016). A study has reported that sainfoin had reduced egg hatchability of Trichostrongylus colubriformis and inhibited the egg development of nematodes and lungworm (Strongyloides spp., Ostertagia spp., Cooperia spp., Oesophagostomum spp. and Trichostrongylus spp.) (Molan et al., 2000; Yuxi et al., 2015). These consequences were dose dependent. Azuhnwi et al. (2013) observed that sainfoin reduced the shedding of Haemonchus eggs on pasture which can reduce chances of pasture contamination and prevent the gut parasitic infection (Azuhnwi et al., 2013). Another study exposed that heifers fed mimosa (Acacia mearnsii), and chestnut (Castanea sativa) tannins diet had reduced Cooperia and Ostertagia fecal egg count but $H$. contortus were unaffected (Min et al., 2015). Moreover, worm egg count and worm fecundity for Nematodirus battus and Trichostrongylus colubriformis (intestinal species) was reduced by feed application of CT plants in sheep, however there was no difference for Teladorsagia circumcincta and $H$. contortus (stomach and abomasum species) (Luque et al., 2000). It is possible that the efficacy of plant purified tannin against $H$. contortus was due to short residence time of larvae in gut ecosystem at less than $30 \mathrm{~min}$ (Pathak et al., 
2013), signifying that direct contact between tannins and nematodes might require to reduce worm load or larval development in host animals.

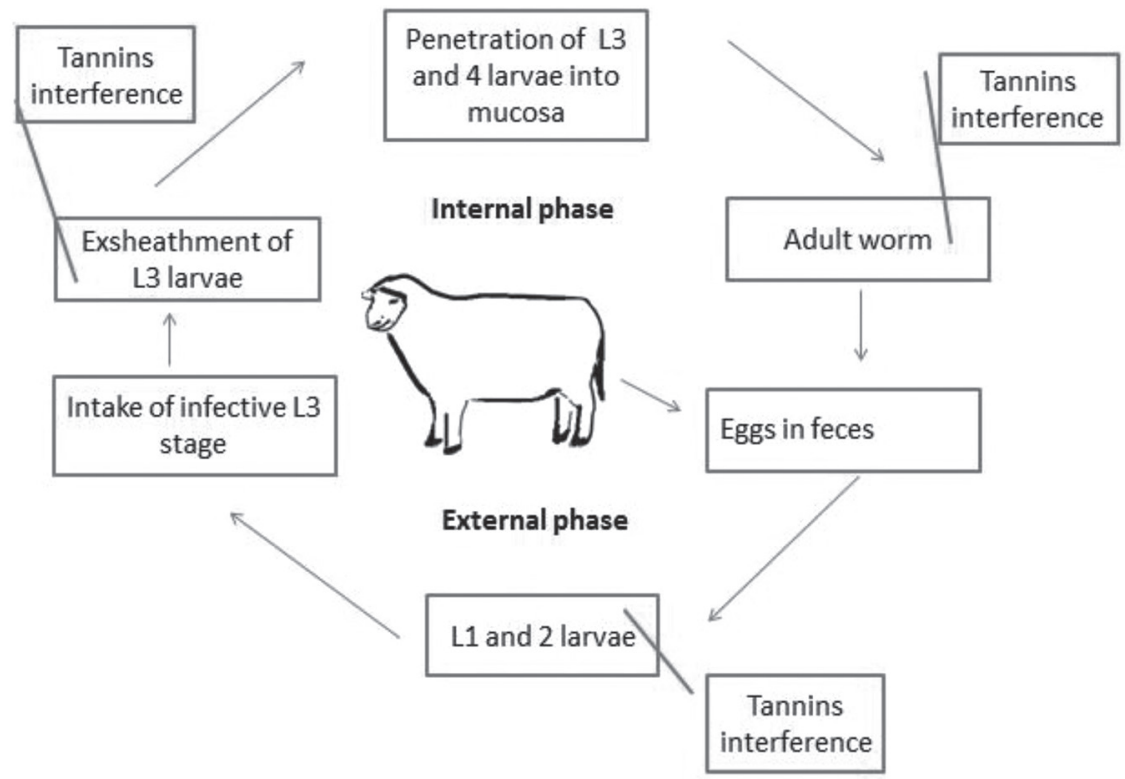

Figure 3. Effect of tannins on parasitic infection (Paolini et al., 2005)

Table 7. Effect of tannins on gut parasite

\begin{tabular}{|c|c|c|c|}
\hline Plant source & Species & Effects & References \\
\hline 1 & 2 & 3 & 4 \\
\hline $\begin{array}{l}\text { CT containing quebracho } \\
\text { (Schinopsis } s p \text {.) bark } \\
\text { extract }\end{array}$ & Goat & $\begin{array}{l}\text { Decreased in the development of third larval } \\
\text { stage of Haemonchus contortus; Reduced } \\
\text { worm fertility and egg count }\end{array}$ & $\begin{array}{l}\text { Paolini et al. } \\
(2003)\end{array}$ \\
\hline $\begin{array}{l}\text { CT extract from legume } \\
\text { tanniferous forages }\end{array}$ & In vitro & $\begin{array}{l}\text { Reduced egg hatching and larval develop- } \\
\text { ment of Trichostrongylus colubriformis }\end{array}$ & $\begin{array}{l}\text { Molan et al. } \\
(2002)\end{array}$ \\
\hline CT containing plants & Sheep & $\begin{array}{l}\text { Reduced worm numbers and worm fecun- } \\
\text { dity for the intestinal parasite (T. colubrifor- } \\
\text { mis and Nematodirus battus); No effect for } \\
\text { the abomasum species (Haemonchus con- } \\
\text { tortus and Teladorsagia circumcincta) }\end{array}$ & $\begin{array}{l}\text { Athanasiadou } \\
\text { et al. (2001) }\end{array}$ \\
\hline CT containing feedstuffs & Goat & $\begin{array}{l}\text { Reduced adult worm fecundity of } T \text {. colu- } \\
\text { briformis and } H \text {. contortus; } T \text {. circumcincta } \\
\text { were unaffected }\end{array}$ & $\begin{array}{l}\text { Pathak et al. } \\
\text { (2013) }\end{array}$ \\
\hline
\end{tabular}


Table 7 - contd.

\begin{tabular}{|c|c|c|c|}
\hline 1 & 2 & 3 & 4 \\
\hline \multirow[t]{2}{*}{$\begin{array}{l}\text { CT containing chicory } \\
\text { (Cichorium intybus) }\end{array}$} & Sheep & $\begin{array}{l}\text { Decreased number of } T \text {. circumcincta but } \\
\text { Trichostrongylus } \mathrm{sp} \text { were unaffected; }\end{array}$ & $\begin{array}{l}\text { Molan et al. } \\
(2003)\end{array}$ \\
\hline & $\begin{array}{c}\text { Young } \\
\text { deer }\end{array}$ & $\begin{array}{l}\text { Hindered the motility of Dictyocaulus sp } \\
\text { (lungworm) first larvae (L1); No effects } \\
\text { on the egg hatching and development of } \\
\text { nematode larvae; Reduced the viability of } \\
\text { lungworm and intestinal larvae; Reduced } \\
\text { lungworm infections }\end{array}$ & \\
\hline $\begin{array}{l}\text { CT with a crude extract } \\
\text { containing sesquiterpene } \\
\text { lactones from chicory }\end{array}$ & Deer & $\begin{array}{l}\text { Reduced the motility of first (L1) and third } \\
\text { (L3) larvae of lungworm; Hindered third } \\
\text { larval (L3) mixed species of gastrointestinal }\end{array}$ & $\begin{array}{l}\text { Jackson et al. } \\
(2006)\end{array}$ \\
\hline
\end{tabular}

leaves

\begin{tabular}{|c|c|c|c|}
\hline $\begin{array}{l}\mathrm{CT} \text { containing sulla }(\mathrm{He}- \\
\text { dysarum coronarium) }\end{array}$ & Lamb & $\begin{array}{l}\text { Decreased egg counts of Trichostrongylus } \\
\text { colubriformis and Ostertagia circumcincta }\end{array}$ & $\begin{array}{l}\text { Niezen et al. } \\
(2002)\end{array}$ \\
\hline $\begin{array}{l}\mathrm{CT} \text { containing extract } \\
\text { from plants }\end{array}$ & Sheep & $\begin{array}{l}\text { Decreased levels of parasitism; In vivo } \\
\text { reduced infection of } T \text {. colubriformis }\end{array}$ & $\begin{array}{l}\text { Athanasiadou et } \\
\text { al. (2005) }\end{array}$ \\
\hline $\begin{array}{l}\text { Forage containing chicory } \\
\text { (Cichorium intybus), sulla } \\
\text { (Hedysarum coronarium) } \\
\text { and lotus (Lotus pedun- } \\
\text { culatus) }\end{array}$ & Sheep & $\begin{array}{l}\text { Reduced worm load of } T \text {. circumcincta and } \\
\text { larval development }\end{array}$ & $\begin{array}{l}\text { Tzamaloukas et } \\
\text { al. (2005) }\end{array}$ \\
\hline $\mathrm{CT}$ containing sainfoin & Goat & $\begin{array}{l}\text { Reduced infections of nematode and in- } \\
\text { creased resistance against nematode }\end{array}$ & $\begin{array}{l}\text { Paolini et al. } \\
\text { (2005) }\end{array}$ \\
\hline $\begin{array}{l}\text { Mimosa (Acacia mearn- } \\
\text { sii) and chestnut (Casta- } \\
\text { nea sativa) }\end{array}$ & Heifers & $\begin{array}{l}\text { Decreased Cooperia and Ostertagia fecal } \\
\text { egg count; H. contortus were unaffected }\end{array}$ & $\begin{array}{l}\text { Min et al. }(2015 \\
\text { a, b) }\end{array}$ \\
\hline $\begin{array}{l}\text { CT containing L. cornicu- } \\
\text { latus }\end{array}$ & Lamb & $\begin{array}{l}\text { Strongyloid nematode parasites in lambs } \\
\text { grazing } L \text {. corniculatus suggest a decrease } \\
\text { in the degree of parasite control from the } \\
\text { abomasum to the rectum }\end{array}$ & $\begin{array}{l}\text { Piluzza et al. } \\
\text { (2013) }\end{array}$ \\
\hline $\begin{array}{l}\text { CT-containing forages } \\
\text { (H. coronarium and } L \text {. } \\
\text { pedunculatus) }\end{array}$ & & $\begin{array}{l}\text { Reduced worm burden of strongyloid nem- } \\
\text { atode from the abomasum to the rectum; } \\
\text { Enhanced resistant to parasite infection and } \\
\text { reduced gut worm load }\end{array}$ & \\
\hline $\begin{array}{l}\text { CT containing leaves of } \\
\text { Lysiloma acapulcensis }\end{array}$ & Lamb & $\begin{array}{l}\text { Decreased the parasitic infection and fecal } \\
\text { egg counts at dose of } 37.5 \mathrm{mg} / \mathrm{kg} \mathrm{BW}\end{array}$ & $\begin{array}{l}\text { García-Hernán- } \\
\text { dez et al. (2017) }\end{array}$ \\
\hline
\end{tabular}

Ruminant fed mimosa and chestnut tannins diet had decreased Cooperia fecal eggs count by 8 to $13 \%$, respectively. However, heifers fed chestnut tannins had $57 \%$ reduced Ostertagia fecal eggs count at day 41 when compared with control group (without CT feed) (Min et al., 2015). A trial in sheep has observed that plant extracts containing $C$. quadrangularis had reduced egg hatchability $88 \%$ at concentration of $1 \mathrm{mg} / \mathrm{ml}$. Whereas, ruminants given Schinus molle caused $95 \%$ mortality of adult parasites at concentration of $10 \mathrm{mg} / \mathrm{ml}$ and reduced by $96 \%$ egg hatchability for $H$. contortus at concentration of $1 \mathrm{mg} / \mathrm{ml}$ (Zenebe et al., 2017). The mechanism of 
action how CT produce anthelmintic effect is still unknown, but there is a possibility that CT cause paralysis, worms mortality and/or hindrance in worms (larval stage) motility in gastrointestinal tract.

\section{Anti-bloat effects of tannins}

CT extract from legume forages (Lotus corniculatus, Coronilla varia, Onobrychis vicciifolia or Astragalus cicer L.) fed sole diet or mixed with bloat forming fodder play a key role in the prevention of ruminal bloat by making protein-complexes in the rumen (Mueller-Harvey, 2006; Rochfort et al., 2008; Yuxi et al., 2012). Tanniferous fodder such as sainfoin, Lotus spp. does not cause bloat at low concentration of $1-5 \mathrm{~g} / \mathrm{kg}$ (Abeynayake et al., 2011). The exact mechanism how tannins prevent bloat is still unclear. But, it is proposed that $\mathrm{CT}$ prevent bloat by inhibition of slime-producing bacteria or disrupting the reaction of proteinaceous frothy foam (Ehsan et al., 2013; Addisu, 2016). Therefore, tannin-containing plants have been considered in ruminants production.

\section{Enteric methane emission}

Methane production is a normal and important process in ruminants (Figure 4). Hydrogen $\left(\mathrm{H}_{2}\right)$ is produced in the rumen during fermentation and methanogens use $\mathrm{H}_{2}$ as an energy source (Janssen, 2010), which results in $\mathrm{CH}_{4}$ (methane) formation. The microorganisms that produce methane as a byproduct of their respiration are called methanogens and the whole process of $\mathrm{CH}_{4}$ formation is called methanogenesis (Jafari et al., 2019). $\mathrm{CH}_{4}$ is produced as a result of feed fermentation in the rumen. However, about $89-90 \%$ of $\mathrm{CH}_{4}$ is produced in the rumen and exhaled by the mouth and nose (Kempton et al., 1976; Kumar et al., 2014 a, b). A study has reported that in young calf, the process of $\mathrm{CH}_{4}$ production and expulsion begins at the age of 4 weeks when the reticulorumen starts to develop (Jafari et al., 2019). $\mathrm{CH}_{4}$ is more hazardous than $\mathrm{CO}_{2}$ which causes climatic changes and affects the global warming (Bodas et al., 2012). Hence, there is need to find alternative feed additives to mitigate enteric $\mathrm{CH}_{4}$ emission in order to secure green environment and livestock production.

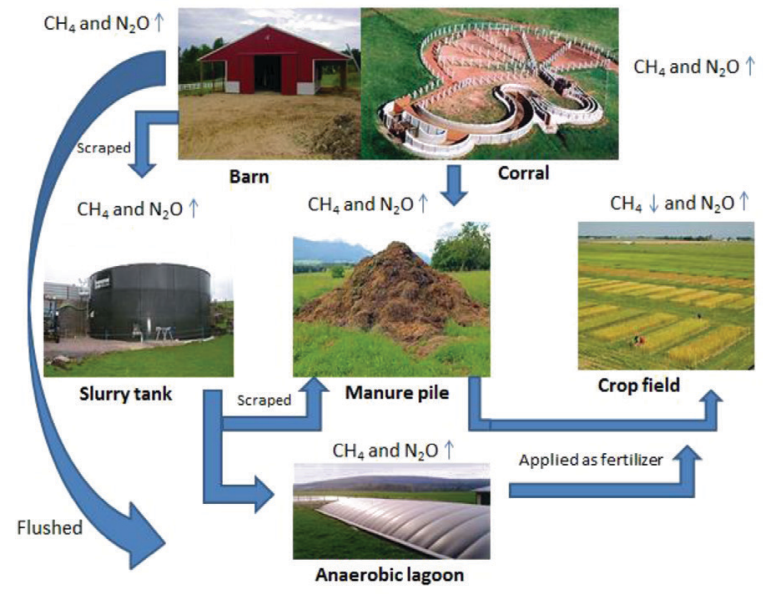

Figure 4. Mechanism of methane production and emission (Jafari et al., 2019) 


\section{Dietary tannins application to reduce methane emission}

Mitigation opportunities to reduce $\mathrm{CH}_{4}$ production is a big challenge. Several techniques of $\mathrm{CH}_{4}$ inhibition have been used to mitigate the enteric $\mathrm{CH}_{4}$ (Patra and $\mathrm{Yu}, 2014)$. But, some of them have harmful effects on ruminant microbiology and fermentation especially at high concentration (Patra and Yu, 2013). Moreover, various $\mathrm{CH}_{4}$ inhibitors are toxic to ruminants (Patra and $\mathrm{Yu}, 2012$ ). In the meantime, modern consumer demands to use natural products like phytochemicals to modify rumen ecosystem. More than 200,000 plant secondary metabolites (PSM) structures have been identified (Hartmann, 2007), but most of PSM have been categorized into three main classes: tannins, essential oils and saponins (Bhatta et al., 2014). Especially tannins such as HT and CT are complex class of PSM that have complex structures and biological activities (Bhatta et al., 2009).

From the last few decades, the utilization of tannins in animal nutrition has been addressed in the previous in vitro and in vivo studies. A study has recorded that about $25 \%$ of the global anthropogenic methane $\left(\mathrm{CH}_{4}\right)$ emission is produced by enteric fermentation in the animals, and this proportion has increased almost $50 \%$ in the rural societies, which contribute more than $90 \%$ by rumen fermentation (Abberton et al., 2008; Kumar et al., 2014 a, b; Jafari et al., 2019). Greenhouse gases such as methane $\left(\mathrm{CH}_{4}\right)$, carbon dioxide $\left(\mathrm{CO}_{2}\right)$, nitrous oxide $\left(\mathrm{N}_{2} \mathrm{O}\right)$, and ozone $\left(\mathrm{O}_{3}\right)$ cause environmental variation and affect the global warming by infrared radiation in the atmosphere (Lashof and Ahuja, 1990). Methane is classified as a trace gas that is expected to have a worldwide concentration of $1774 \pm 1.8$ parts per billion (ppb), with overall increase of $11 \mathrm{ppb}$ since 1998 (Hook et al., 2010). Specially, it is an intoxicating trace gas due to its global warming action, 25 times higher than $\mathrm{CO}_{2}$ with 12 year atmospheric lifetime (Ellis et al., 2007; Hook et al., 2010). Thus, $\mathrm{CH}_{4}$ is considered as the second largest anthropogenic greenhouse gas after $\mathrm{CO}_{2}$ (Hook et al., 2010). It has been reported that $50-60 \%$ of $\mathrm{CH}_{4}$ emissions is produced from agricultural areas, particularly from livestock and ruminants are categorized as the primary source of $\mathrm{CH}_{4}$ production (Ellis et al., 2007; Hook et al., 2010).

Numerous studies have indicated that 80 million tons $\mathrm{CH}_{4}$ are produced annually worldwide (Eckard et al., 2010), of which almost $47 \%$ are contributed from agricultural areas and 39\% from livestock (Ellis et al., 2010; Hook et al., 2010; Gerber et al., 2013). Comparatively, ruminants are higher producers of $\mathrm{CH}_{4}$ as compared to monogastric animals (Gunun et al., 2017). Farm animals such as ruminant species (cattle, sheep, and goats) produce almost 86 million metric tons $(\mathrm{Tg}) \mathrm{CH}_{4} /$ year $(\mathrm{McMi}-$ chael et al., 2007). Another similar study has observed that almost $18.9 \mathrm{Tg}, 55.9 \mathrm{Tg}$ and $9.5 \mathrm{Tg} \mathrm{CH}_{4}$ is produced from dairy cattle, beef cattle, and small ruminants (sheep and goats), respectively (McMichael et al., 2007). Johnson and Johnson (1995) have provided data of annual global $\mathrm{CH}_{4}$ production. The above authors have exposed that 6.2-8.1 Tg and 0.9-1.1 $\mathrm{Tg} \mathrm{CH}_{4}$ are produced from buffalo and camels, respectively.

$\mathrm{CH}_{4}$ emissions undergo a loss of $2-12 \%$ of gross energy intake in ruminants that contributes to the global warming (Wanapat et al., 2015). Another study has reported that cattle produce $60-160 \mathrm{~kg} \mathrm{CH}_{4}$ /year and small ruminants (sheep and goats) produce $10-16 \mathrm{~kg} \mathrm{CH}_{4}$ /year, depending on feed types, particle size and dry mater intake (DMI) (Hristov et al., 2013). Mueller-Harvey (2006) examined that 
ruminants consuming highly nutritive diet increase the greenhouse gases (MuellerHarvey, 2006). Puchala et al. (2005) reported that ruminants fed CT extract from L. cuneata had $180 \mathrm{~g} / \mathrm{kg}$ reduced $\mathrm{CH}_{4}$ as compared to those plants containing Digitaria ischaemum (Schreb.) and Festuca arundinacea (Schreb). A study has revealed that tannin containing L. pedunculatus and Salix caprea (goat willow) diet decreased $\mathrm{CH}_{4}$ emissions from the rumen (16 to 20\% per unit intake) (Waghorn et al., 2002; Wallace et al., 2002). However, L. corniculatus based silage also reduced $\mathrm{CH}_{4}$ by $23 \%$ per unit intake $\left(\mathrm{g} \mathrm{CH}_{4} / \mathrm{kg} \mathrm{DM}\right.$ intake) and by $13 \%$ per unit production $\left(\mathrm{g} \mathrm{CH}_{4} / \mathrm{kg}\right.$ milk solids) (Woodward et al., 2001). Conversely, some studies have explained that tannin containing diets can reduce methane emissions from ruminants.

Several authors have discussed that CT and saponins have ability to reduce enteric $\mathrm{CH}_{4}$ emission (Figure 5) (Wanapat et al., 2014; Anantasook et al., 2016; Gunun et al., 2017). A trial in ruminants has observed that dietary rambutan peel (RP) had significant effect on protozoa and methanogens via modification in the rumen ecosystem (Gunun et al., 2018). In the above study, RP (Nephelium lappaceum L.) was composed of CT and saponins (Gunun et al., 2018). Ruminants supplemented with $16 \mathrm{mg}$ RP increased the rumen metabolism and reduced methane emission. Furthermore, addition of CT containing mangosteen peel in ruminants fed at dose of 2-6\% DM had decreased total gas production (Paengkoum et al., 2015). In vitro study has observed that $8 \%$ addition of CT plants extracts in feed reduced $\mathrm{CH}_{4}$ by $30 \%$ (Denek et al., 2017). $\mathrm{CH}_{4}$ and protozoal population was reduced by addition of RP with $0.2-0.6 \%$ saponins (Gunun et al., 2018).

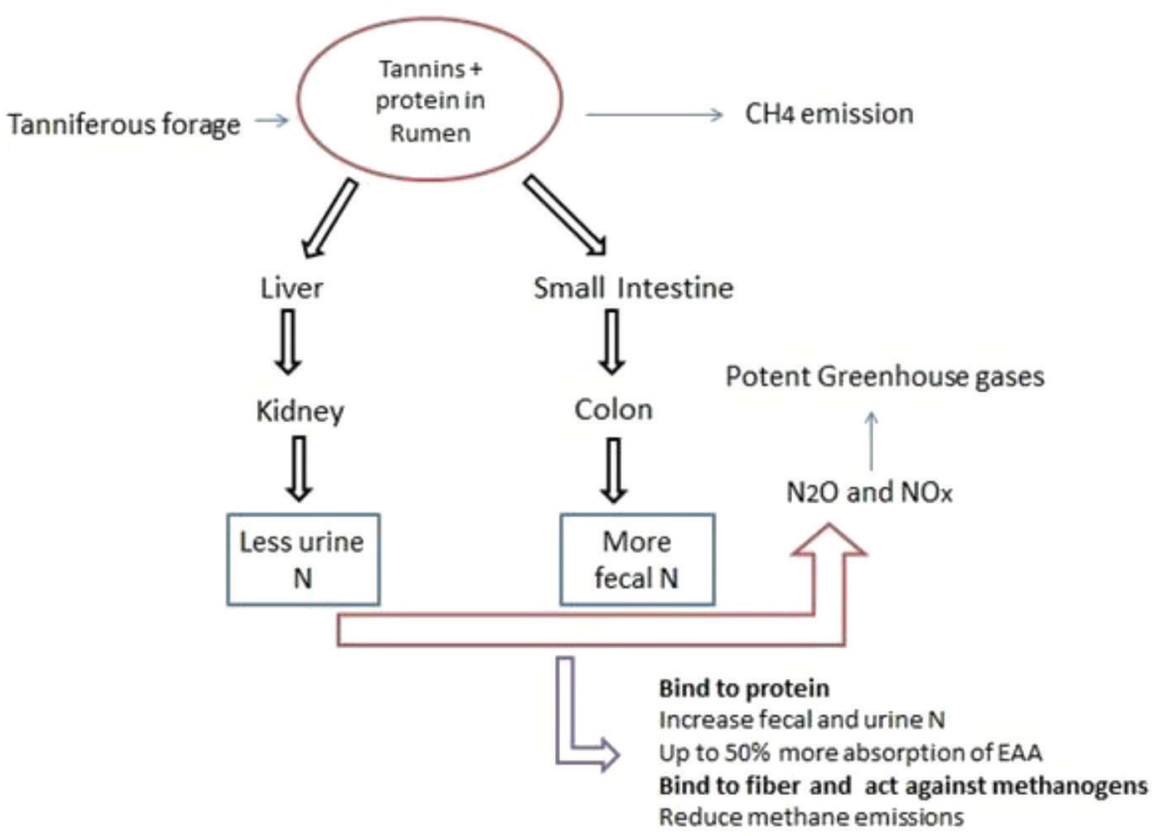

Figure 5. Effect of tannins on methane emission (Patra et al., 2016) 
However, it is very important to note that methanogenesis can be reduced by hindering the production of $\mathrm{H}_{2}$ and methanogens by the application of CT (Tavendale et al., 2005; Pathak et al., 2017). Bhatta et al. (2009) observed that methanogenesis in rumen can be inhibited primarily by decreasing the methanogen or the protozoal population by supplementation of tannins rich plants. Furthermore, it has been observed that both tannins supplementation (HT and CT) have potential to inhibit methanogenesis as compared to those diets without tannins supplementation. In another study, Guglielmelli et al. (2011) reported that plant phenoloic forage (sainfoin) given to ruminants had decreased in vitro $\mathrm{CH}_{4}$ production. While gallotannins feed containing $\mathrm{HT}$ caused $50 \%$ hindrance of $\mathrm{CH}_{4}$ production with less injurious effect on ruminants as compared to monomers vs. polymers plants (Bhat et al., 1998).

In vitro study investigated that $\mathrm{CT}$ based Acacia cyanophylla supplemented at $60 \%$ and $30 \%$ reduced $\mathrm{CH}_{4}$ production by $37.5 \%$ and $56.25 \%$, respectively (Rira et al., 2015). The results were attributed to high CT concentration in Acacia cyanophyl$l a$ which was recorded toxic for rumen microbes, particularly methanogens, ciliate protozoa and fiber degrading microbes (Kamra et al., 2006). Moreover, $\mathrm{CH}_{4}$ production was inhibited by Acacia cyanophylla supplementation due to modification in the profile of volatile fatty acid and increases in the concentration of propionate (Kamra et al., 2006). Jayanegara et al. (2015) described that tannins containing plants such as sumac, chestnut, quebracho and mimosa given at concentration of $1 \mathrm{mg} / \mathrm{mL}$ of rumen liquid decreased ruminal $\mathrm{CH}_{4}$ emissions, which was in accordance with previous results which stated that tannins have inhibitory effect on rumen methanogenesis (Jayanegara et al., 2012). Thus, both in vitro and in vivo studies concluded that increased tannin concentration ( 0 to $177 \mathrm{~g} / \mathrm{kg}$ ) significantly decreased $\mathrm{CH}_{4}$ production (Jayanegara et al., 2012).

Interestingly, all studies have confirmed that both HT plus CT plants were effective in reducing in vitro $\mathrm{CH}_{4}$ production as compared to only HT based diet (Bhatta et al., 2012). But, tannin extracts containing phenolic fractions were more effective compared with plant leaves comprising tannins (Bhatta et al., 2009). A study by Bhatta et al. (2014) exposed that tannins have direct inhibitory effects on methanogenesis by affecting rumen specific microorganisms named archaea because protozoa provides $\mathrm{H}_{2}$ to methanogens as a source of electrons and therefore, tannins reduce $\mathrm{CH}_{4}$ production by its antiprotozoal activity against methanogens. The effect of CT and HT was different on ruminal protozoa due to less inhibitory action of HT against protozoa as compared to CT (Śliwiński et al., 2002; Pinski et al., 2015). However, CT concentration at $50 \mathrm{~g} / \mathrm{kg}$ of DM did not affect the parameters of ruminal fermentation. Beauchemin and McGinn (2006) also reported that addition of quebracho tannin extract at $2 \%(1.8 \% \mathrm{CT})$ of DM was not suitable to reduce $\mathrm{CH}_{4}$ production. However, another in vitro and in vivo study by Jayanegara et al. (2012) revealed that higher tannin concentrations at $177 \mathrm{~g} / \mathrm{kg}$ reduced $\mathrm{CH}_{4}$ production. It is proposed that the difference in results was due to tannin supplement sources, concentration, composition, dosage and the period of tannins adaptation.

Very specifically, another study showed that lambs supplemented with tannins based plants leaf mixture (Ficus infectoria and Psidium guajava) at concentration of $1 \%$ to $2 \%$ had significantly reduced $\mathrm{CH}_{4}$ emission (Dubey et al., 2011). It has 
been proposed that the positive effect of tannins was probably due to the following three reasons i) direct effect on methanogens growth in the rumen (Williams et al., 2011 ) ii) indirect effect on methanogens by less availability of hydrogen for rumen microorganisms (Patra, 2010) iii) inhibitory effect of CT on methanogenesis that can reduce the ratio of acetate to propionate (Hatew et al., 2016), which may increase transfer of hydrogen to propionate. They concluded that tannins could affect rumen methanogenesis without affecting the other fermentation parameters and their impact on rumen fermentation was different according to their specific type, source and concentration. Therefore, it has been now confirmed by several studies that $\mathrm{CH}_{4}$ production can be reduced by inhibiting the population of protozoa and methanogens through supplementation of tanniferous forages (Table 8), which can be helpful to improve livestock production and control climatic changes in the future (Anantasook et al., 2015; Pathak et al., 2017).

Table 8. Effect of tannins on methane emission

\begin{tabular}{|c|c|c|c|}
\hline Plant source & & Effects & References \\
\hline 1 & 2 & 3 & 4 \\
\hline $\begin{array}{l}\text { CT containing Acacia } \\
\text { mearnsii }\end{array}$ & Sheep & $13 \%$ reduced methanogensisis & Carulla et al. (2005) \\
\hline $\begin{array}{l}\text { Condensed tannin } \\
\text { extract (Schinopsis } \\
\text { quebracho-colorado) } \\
\text { and tannin containing } \\
\text { sorghum silage }\end{array}$ & Cattle & No effect on methanogenesis & $\begin{array}{l}\text { Beauchemin et al. } \\
\text { (2007) De Oliveira } \\
\text { et al. (2007) }\end{array}$ \\
\hline $\begin{array}{l}\text { CT based L. peduncula- } \\
\text { tus or L. corniculatus }\end{array}$ & $\begin{array}{l}\text { In vivo } \\
\text { (ruminants) }\end{array}$ & $\begin{array}{l}\text { Reduced methane }(20-30 \%) \text { per unit of } \\
\text { digestible dry matter intake (DDMI); } \\
\text { Reported HTs and CTs toxicity towards } \\
\text { methanogens in methanogenic digesters }\end{array}$ & $\begin{array}{l}\text { Jouany and Morgavi } \\
(2007)\end{array}$ \\
\hline $\begin{array}{l}\text { CT containing } \\
\text { Callinada calothyrsus } \\
\text { and Fleminga macro- } \\
\text { phylla }\end{array}$ & Lambs & $24 \%$ reduced methane emission & $\begin{array}{l}\text { Tiemann et al. } \\
(2008)\end{array}$ \\
\hline $\begin{array}{l}\text { CT containing mimosa } \\
\text { and quebracho tannin } \\
\text { HT containing chestnut }\end{array}$ & Sheep & $\begin{array}{l}\text { Affect all microbes but less effect on } \\
\mathrm{N}_{2} \mathrm{O} \text { and methane; } \\
\text { Less effect on } \mathrm{N}_{2} \mathrm{O} \text { and no effect on } \\
\text { methane and microbes }\end{array}$ & $\begin{array}{l}\text { Deaville et al. } \\
\text { (2010) }\end{array}$ \\
\hline $\begin{array}{l}\text { Condensed tannin } \\
\text { containing } \\
\text { Lespedeza cuneata }\end{array}$ & Goats & Reduced methane about $57 \%$ & Hook et al. (2010 a) \\
\hline CT containing sainfoin & Sheep & $\begin{array}{l}\text { Affect methanogens but less effect on } \\
\mathrm{N}_{2} \mathrm{O} \text { and methane }\end{array}$ & $\begin{array}{l}\text { Theodoridou et al. } \\
(2010)\end{array}$ \\
\hline $\begin{array}{l}\text { Hydrolysable tannin } \\
\text { supplementation }\end{array}$ & Ruminants & Reduce methane emission & $\begin{array}{l}\text { Menezes et al. } \\
(2011)\end{array}$ \\
\hline $\begin{array}{l}\text { CT containing grape- } \\
\text { seed } \\
\text { HT containing valonea } \\
\text { HT containing my- } \\
\text { rabolan }\end{array}$ & In vitro & $\begin{array}{l}\text { Affect methanogens and all microbes } \\
\text { but less effect on methane }\end{array}$ & $\begin{array}{l}\text { Pellikaan et al. } \\
\text { (2011) }\end{array}$ \\
\hline
\end{tabular}


Table 8 - contd.

\begin{tabular}{|c|c|c|c|}
\hline 1 & 2 & 3 & 4 \\
\hline $\begin{array}{l}\text { Condensed tannins (pine } \\
\text { bark) }\end{array}$ & Goat & $\begin{array}{l}\text { Decreased Methanobrevibacter popula- } \\
\text { tion }\end{array}$ & Min et al. (2014) \\
\hline $\begin{array}{l}\text { Condensed tannins in } \\
\text { vitro }\end{array}$ & Bovine & $\begin{array}{l}\text { Decreased Methanobrevibacter popula- } \\
\text { tion }\end{array}$ & $\begin{array}{l}\text { - Saminathan et al. } \\
\text { (2016) }\end{array}$ \\
\hline $\begin{array}{l}\text { CT containing quebra- } \\
\text { cho }\end{array}$ & Steers & $\begin{array}{l}\text { Reduce Methanosphaera and methano- } \\
\text { genic archaea; } \\
\text { Methanogens (phylum Euryarchaeota) } \\
\text { were less abundant in steers ( } 1.37 \text { ver- } \\
\text { sus } 2.03 \% \text { ) }\end{array}$ & Juan et al. (2017) \\
\hline $\begin{array}{l}\text { Grape marc (skin, stalk, } \\
\text { stem and seed) }\end{array}$ & Dairy cows & $20 \%$ reduced $\mathrm{CH}_{4}$ emissions & Moate et al. (2014) \\
\hline $\begin{array}{l}\text { HT containing chestnut } \\
\text { and valonea extract }\end{array}$ & In vitro & $\begin{array}{l}\text { Decreased methane emission (14 to } \\
17 \% \text { ) }\end{array}$ & $\begin{array}{l}\text { Wischer et al. } \\
(2013)\end{array}$ \\
\hline
\end{tabular}

\section{Safety and risk associated with dietary tannins}

Tannins as a natural alternative feed additive are safe (dose dependent) for all animals and have not reported any environmental hazards. On the other hand, in vitro trial has investigated genotoxicity in rats, but in vivo genotoxicity and oral exposure carcinogenicity has not been recognized. The European Food Safety Authority (EFSA) Panel on Additives and Products or Substances used in Animal Feed (FEEDAP) also did not categorize tannins based reproductive toxicity. However, FEEDAP panel have reported that tannins cause hazardous effects in workers via inhalation or exposure through direct contact with the skin, eye and mucous membrane (EFSA, 2014). Several findings demonstrated that high concentration of chestnut tannins caused liver and kidney toxicity in ruminants, but no adverse effects were found on the liver, kidney, stomach, and the small intestine in neonatal pigs and rats during 28 days trial (Min et al., 2015). The European Food Safety Authority has suggested that tannins high concentrations as compared to recommended concentration cause toxicity such as toxic level of tannins supplementation in adult ruminants and young calf is $>15000$ and $>1500 \mathrm{mg} / \mathrm{kg}$ feed, respectively, while safe level of tannins application in adult ruminants and young calf is 15000 and $1500 \mathrm{mg} / \mathrm{kg}$ feed, respectively. Taken together, various studies showed that $15 \mathrm{mg}$ tannic acid/ $\mathrm{kg}$ diet is safe for all animals (EFSA, 2014). Therefore, it is recommended that caution should be taken before the applications of tannins in animal ration in order to achieve the positive consequences.

\section{Conclusion and recommendation}

Livestock production has significant role to eliminate poverty of millions of people and build a healthy society. Recently, the world is facing several challenges including food security, greenhouse effects, global warming and increasing global population. Antibiotic growth promoters cause microbial resistance in food animals and create food safety issues (drug resistance) in humans. Therefore, it is necessary to investigate natural alternatives to antibiotic feed additives. Regarding the above 
issue, tannins have been classified as an alternative to antibiotic growth promoters. Tanniferous plants have potential to improve ruminant production and minimize the problem of global warming. Tannins containing forages have antimicrobial, antiparasitic and anti-bloat characteristics which, in turn, may improve rumen fermentation, protein absorption, energy efficiency (reducing methane emission), milk yield and fatty acid composition which, in turn, enhance ruminant production. In addition, methane mitigation strategies may not only improve ruminant production but also reduce the contribution of global methane emission from livestock. Hence, it has been clearly reported that tannin associated beneficial and deleterious effects are dose, duration, source, concentration and composition dependent. Thus, preventive measures should be used before the applications of tannins in ruminant nutrition in order to achieve the optimum production.

\section{Gaps in the literature and recommendation for future study}

However, due to a lack of sufficient studies on the presence of hydrolysable tannins in leaves of trees and shrubs, further studies are needed to exploit the full potential of this approach.

Quantification in vitro of the tannin-induced protection of proteins from degradation in the rumen in combination with measurement of gas and microbial mass may predict effects of tannins in the rumen. Hence, an in vitro approach simulating the absorptive phase should be developed to study the effects of tannins on the absorption of nutrients.

Comparison of tannin levels (by using an array of methods) in a plant species grown under well-defined environmental conditions in a glasshouse will also advance knowledge on the factors controlling tannin biosynthesis. Thereby, comparison of accessions of the same types of trees/shrubs planted at different locations should be investigated to identify unequivocally the factors influencing tannin biosynthesis.

Tannins have a strong anti-oxidant activity but very little is known on the significance of tannins in ruminants with respect to their anti-oxidation property. Therefore, studies should be conducted to know the 'threshold level' of tannins in a feedstuff below which these have beneficial effects on livestock.

Furthermore, molecular biology may help to explore the structural diversity relationships of tannin forages. Such finding might be helpful for better understanding the nutritional properties of tannin-containing fodder in future.

\section{Abbreviation}

ADG, average daily gain; $\boldsymbol{\alpha}$-LNA, $\alpha$-linolenic acid; BCS, body condition score; $\mathbf{C H}_{4}$, methane condition score; $\mathbf{C L A}$, conjugated linoleic acid; $\mathbf{C O}_{2}$, carbon dioxide; CT, condensed tannins; DM, dry matter; DMI, dry matter intake; EAA, essential amino acid; EFSA, European Food Safety Authority; FAO, Food and Agriculture Organization; FEEDAP, EFSA Panel on Additives and Products or Substances used in Animal Feed; GSE, grape seed extract; GSSE, grape seed skin extract; $\mathbf{H}_{2}$, hydrogen; HT, hydrolysable tannins; IPCC, Intergovernmental Panel on Climate Change; LA, linoleic acid; LW, live weight; QT, quebracho tannins; RP, rambutan 
peel; RUP, rumen undegradable protein; TBSP, tannin-binding salivary proteins; WG, weight gain.

\section{Declarations}

\section{Ethics approval and consent to participate}

According to rules and regulation of Animal Care Committee of Guangdong Ocean University (Guangzhou, People's Republic of China)

\section{Consent for publication}

Not applicable.

\section{Availability of data and materials}

Data sharing is not applicable to this article.

\section{Competing interests}

All authors declare that they have no competing interests.

\section{Funding}

Not applicable.

\section{Authors' contributions}

AN wrote the main text of manuscript. GL and YN collected the data. LA have contributed to double checking grammar. YZ and MX participated in its design and coordination. ST and CS contributed to drafting and the revision of the paper. All authors read and approved the final manuscript.

\section{Acknowledgments}

Special thanks to Annals of Animal Science journal for giving opportunity to share knowledge on natural feed resources. In addition, Dr. Jiang Wu, Muhammad Waseem Birmani and Muhammad Waseem Ghani names have been added in acknowledgements section due to technical help in editing of the manuscript. The author wishes to thank teachers, parents (Rana Nawab Ahmad and Mrs. R Sultana), uncle (Rana Maqbool Ahmad) for continued support and excellent mentorship. This work was supported by Science and Technology Planning Project of Guangdong Province, China (2010 B090400376).

\section{References}

A beynayake S.W., Panter S., Mouradov A., S pangenberg G. (2011). A high-resolution method for the localization of proanthocyanidins in plant tissues. Plant Methods., 7: 2-6.

A bo-Donia F.M., Yang L.Y., Hris tov A.N., Wang M., Tang S.X., Zhou C.S., Han X.F., K a n g J.H., T a n Z.L., H e Z.L. (2017). Effects of tannins on the fatty acid profiles of rumen fluids and milk from lactating goats fed a total mixed ration containing rapeseed oil. Livest. Sci., 204: 16-24.

Aguerre M.J., Capozzolo M.C., Le ncioni P., Cabral C., Watt i a ux M.A. (2016). Effect of quebracho-chestnut tannin extracts at dietary crude protein levels on performance, rumen fermentation, and nitrogen partitioning in dairy cows. J. Dairy Sci., 99: 4476-4486.

A 1 i M., M ehb o ob H.A., Mirza M.A., R a za H., O s redkar M. (2017). Effect of hyrdolysable tannin supplementation on production performance of dairy crossbred cows. J. Anim. Plant Sci., 27: 1088-1093.

A li pour D., Rouzbehan Y. (2010). Effects of several levels of extracted tannin from grape pomace on intestinal digestibility of soybean meal. Livest. Sci., 128: 87-91. 
A lonso-Diaz M.A., Torres-A cost a J.F.J., S a ndoval- Castro C.A., Hos te H. (2011). Comparing the sensitivity of two in vitro assays to evaluate the anthelmintic activity of tropical tannin rich plant extracts against Haemonchus contortus. Vet. Parasit., 181: 360-364.

Anantas ook N., Wanapat M., Cherdthong A., Gunun P. (2015). Effect of tannins and saponins in Samanea saman on rumen environment, milk yield and milk composition in lactating dairy cows. J. Anim. Physiol. Anim. Nutr., 99: 335-344.

An ant a s o k N., Wan a pat M., Gunun P., Cherdthong A. (2016). Reducing methane production by supplementation of Terminalia chebula containing tannins and saponins. Anim. Sci. J., 87: 783-790.

Andrabi S.M, Ritchie M.M., Stimson C., Horadagoda A., Hyde M., Mc Neill D.M. (2005). In vivo assessment of the ability of condensed tannins to interfere with the digestibility of plant protein in sheep. Anim Feed Sci. Technol., 122: 13-27.

Arsenos G., Fortomaris P., Papadopoulos E., Sotiraki S., Stamataris C., Zyg o y i a n n is D. (2009). Growth and meat quality of kids of indigenous Greek goats (Capra prisca) as influenced by dietary protein and gastrointestinal nematode challenge. Meat Sci., 82: 317-323.

A than as iadou S., Kyriazakis I., J a ckson F., Coop R.L. (2001). Direct anthelmintic effects of condensed tannins towards different gastrointestinal nematodes of sheep: in vitro and in vivo studies. Vet. Parasit., 99: 205-219.

Athanasiadou S., Tzamaloukas O., Kyriazakis I., Jackson F., Coop R.L. (2005). Testing for direct anthelmintic effects of bioactive forages against Trichostrongylus colubriformis in grazing sheep. Vet. Parasitol., 127: 233-243.

A t t i a M.F.A., Nour El-d in A.N.M., E1-zarkouny S.Z., E1-za i a H.M. (2016). Impact of quebracho tannins supplementation on productive and reproductive efficiency of dairy cows. J. Anim. Sci., 6: 269-288.

A ufrere J., Dudilieu M., Andueza D., P oncet C., B a um ont R. (2013). Mixing sainfoin and lucerne to improve the feed value of legumes fed to sheep by the effect of condensed tannins. Int. J. Anim. Biosci., 7: 82-92.

Azuhnwi B.N., Hertzberg H., Arrigo Y., Gutzwiller A., Hess H.D., Mu eller-Harvey I., Torgers on P.R., Kreuzer M., D oh m e-M e i e r F. (2013). Investigation of sainfoin (Onobrychis viciifolia) cultivar differences on nitrogen balance and fecal egg count in artificially infected lambs. J. Anim. Sci., 91: 2343-2354.

B a n s o A., A d e y e m o S.O. (2007). Evaluation of antibacterial properties of tannins isolated from Dichrostachys cinerea. Afric. J. Biotechnol., 6: 1785-1787.

B a r ry T.N., M c n a b b W.C. (1999). Review article. The implications of condensed tannins on the nutritive value of temperate forages fed to ruminants. Br. J. Nutr., 81: 263-272.

B e a u c h e m in K.A., M c G in n S.M. (2006). Methane emissions from beef cattle: effects of fumaric acid, essential oil, and canola oil. J. Anim. Sci., 84: 1489-1496.

B e a u ch e m in K.A., M c Ginn S.M., M artinez T.F., M c A 11 is t e r T.A. (2007). Use of condensed tannin extract from quebracho trees to reduce methane emissions from cattle. J. Anim. Sci., 85: 1990-1996.

B el a chew Z., Y is ehak K., Taye T., Jan s s en s G.P.J. (2013). Chemical composition and in sacco ruminal degradation of tropical trees rich in condensed tannins. Czech J. Anim. Sci., 58: $176-192$.

B erard N.C., Wang Y., Wittenberg K.M., Kraus e D.O., Coulman B.E., Mc A 11 is t e r T.A., O m in s k i K.H. (2011). Condensed tannin concentrations found in vegetative and mature forage legumes grown in Western Canada. Canadian J. Plant Sci., 91: 669-675.

B e yene S.T., M lis a L., Gx a sheka M. (2014). Local perceptions of livestock husbandry and rangeland degradation in the highlands of South Africa: implication for development interventions. J. Hum. Ecol., 47: 257-268.

B h a t T.K., S in gh B., S h a r m a O.P. (1998). Microbial degradation of tannins - a current perspective. Biodegrad., 9: 343-357.

B hatt a R., Uyeno Y., Taj i ma K., Takenaka A., Yabumoto Y., Nonaka I., Enishi O., $\mathrm{K}$ uri har a M. (2009). Difference in the nature of tannins on in vitro ruminal methane and volatile fatty acid production and on methanogenic archaea and protozoal populations. J. Dairy Sci., 92: $5512-5522$. 
B hat t a R., S a ravanan M., B aruah L., S a m p a th K.T. (2012). Nutrient content, in vitro ruminal fermentation characteristics and methane reduction potential of tropical tannin-containing leaves. J. Sci. Food Agr., 92: 2929-2935.

B h a t t a R., S a r a va n a n M., B a r u a h L., Pr a s a d C.S. (2014). Effects of graded levels of tannincontaining tropical tree leaves on in vitro rumen fermentation, total protozoa and methane production. J. Applied Microbiol., 118: 557-564.

Bhattarai S., Coulman B., Biligetu B. (2016). Sainfoin (Onobrychis viciifolia Scop): renewed interest as a forage legume for Western Canada. Canadian J. Plant Sci., 756: 748-756.

B odas R., Prieto N., García-González R., Andrés S., Giráldez F.J., López S. (2012). Manipulation of rumen fermentation and methane production with plant secondary metabolites. Anim. Feed Sci. Technol., 176: 78-93.

Buccioni A., Serra A., Minieri S., Mannelli F., Cappucci A., Benvenuti D., Rapac cin i S., C onte G., Mele M. (2015). Milk production, composition, and milk fatty acid profile from grazing sheep fed diets supplemented with chestnut tannin extract and extruded linseed. Small Rumin. Res., 130: 200-207.

B ung l a va n S.J., D u t t a N. (2013). Use of tannins as organic protectants of proteins in digestion of ruminants. J. Livest. Sci., 4: 67-77.

Carras co J.M.D., Cabral C., Redondo L.M., Vis o N.D.P., F a rber M.D., Miyakaw a M.E.F. (2016). Impact of dietary tannins on rumen microbiota of bovines. 2nd International Symposium on Alternatives to Antibiotics (ATA). Challenges and Solutions in Animal Production. OIE Headquarters, Paris, France 12-15 December 2016.

Carreno D., Hervas G., Toral P.G., B elenguer A., Frutos P. (2015). Ability of different types and doses of tannin extracts to modulate in vitro ruminal biohydrogenation in sheep. Anim. Feed Sci. Technol., 202: 42-51.

Carulla J., Kreuzer M., Machmueller A., Hess H. (2005). Supplementation of Acacia mearnsii tannins decrease methanogenesis and urinary nitrogen in forage-fed sheep. Aust. J. Agr. Res., 56: 961-970.

C a rva 1 h o C.O., Cha g a s A.C.S., Cot inguiba F., F u r l a n M., B rito L.G., Chaves F.C.M., S te phan M.P., B izzo H.R., A m a rante A.F.T. (2012). The anthelmintic effect of plant extracts on Haemonchus contortus and Strongyloides venezuelensis. Vet. Parasitol., 183: 260-268.

Chat to padhy a y.K., N o s a n chuk J.D., E in s te in A. (2014). Use of antibiotics as feed additives: a burning question. Front. Microbiol., 5: 1-3.

Deaville E.R., Givens I., Mueller-Harvey I. (2010). Chestnut and mimosa tannin silages: effects in sheep differ for apparent digestibility, nitrogen utilisation and losses. Anim. Feed Sci. Technol., 157: 129-138.

D e n e k N., Ay d in S.S., C a n A. (2017). The effects of dried pistachio (Pistachio vera L.) by-product addition on corn silage fermentation and in vitro methane production. J. Appl. Anim. Res., 45: 185-189.

D e y A., S a r a th i De P. (2014). Influence of condensed tannins from Ficus bengalensis leaves on feed utilization, milk production and antioxidant status of crossbred cows. Asian Australas. J. Anim. Sci., 27: $342-348$.

Doss A., Mubarack H.M., Dhanabalan R. (2009). Antibacterial activity of tannins from the leaves of Solanum trilobatum Linn. Indian J. Sci. Technol., 2: 41-43.

D o u gl a s G.B., S ti en e zen M., Wa g horn G.C., F o o te A.G., P u r c h a s R.W. (1999). Effect of condensed tannins in birdsfoot trefoil (Lotus corniculatus) and sulla (Hedysarum coronarium) on body weight, carcass fat depth, and wool growth of lambs in New Zealand. New Zealand J. Agr. Res., 42: 55-64.

D s chaak C.M., William s C.M., Holt M.S., Eun J., Young A.J., Min B.R. (2011). Effects of supplementing condensed tannin extract on intake, digestion, ruminal fermentation, and milk production of lactating dairy cows. J. Dairy Sci., 94: 2508-2519.

Dubey M., Dutta N., Kusumakar S., Pattanaik A., Banerjee P.S., Singh M. (2011). Effect of condensed tannins supplementation from tanniferous tree leaves on in vitro nitrogen and substrate degradation. Anim. Nutr. Feed Technol., 11: 115-22.

E c k a r d R.J., Gra ing e r C., d e K le in C.A.M. (2010). Options for the abatement of methane and nitrous oxide from ruminant production: A Review. Livest. Sci., 130: 47-56. 
EFSA (2014). Scientific Opinion on the safety and efficacy of tannic acid when used as feed flavouring for all animal species. EFSA, 12: 2-18.

Ehsan O., Abdullah N., Oskoueian A. (2013). Effects of flavonoids on rumen fermentation activity, methane production, and microbial population. Bio. Med. Res. Int., 2013: 1-9.

Eld i n I., Elga ilan i H., I s ha k C.Y. (2014). Determination of tannins of three common acacia species of Sudan. Advan. Chemist., 2014: 1-6.

E 11 is J.L., Kebreab E., Odongo N.E., McBride B.W., Okine E.K., France J. (2007). Prediction of methane production from dairy and beef cattle. J. Dairy Sci., 90: 3456-3466.

E 11 is J.L., B annink A., France J., Kebreab E., Dijkstra J. (2010). Evaluation of enteric methane prediction equations for dairy cows used in whole farm models. Global Change Biol., 16: 3246-3256.

Francisco A., Dentinho M.T., Alves S.P., Portugal P.V., Fernandes F., Sengo S., J e r ó n i m o E. (2015). Growth performance, carcass and meat quality of lambs supplemented with increasing levels of a tanniferous bush (Cistus ladanifer L.) and vegetable oils. Meat Sci., 100: $275-282$.

Frutos P., Hervas G., Giralde z F.J., M a n tecon A.R. (2004). Review. Tannins and ruminant nutrition. Spanish J. Agr. Res., 2: 191-202.

Gai F., G a s c o L., S c hi a v o ne A., Z o c c arat o I. (2011). Nutritional effects of chestnut tannins in poultry and rabbit. In: Tannins: Types, Foods Containing, and Nutrition, Chapter: 12. Nutritional Effects of Chestnut Tannins in Poultry and Rabbit, Publisher: Nova Science Publishers, Inc., Editors: Georgios K. Petridis, pp. 297-306.

García-Hernández C., Arece-García J., Rojo-Rubio R., Mendoza-Martínez G.D. A l barrán-P ortillo B., Vázquez-Armijo J.F., Avendaño-Reyes L., O 1 m edo-Juárez A. (2017). Nutraceutic effect of free condensed tannins of Lysiloma acapulcensis (Kunth) benth on parasite infection and performance of Pelibuey sheep. Trop. Anim. Health Prod., 49: 55-61.

G e m e d a B.S., Has s e n A. (2018). The potential of tropical tannin rich browses in reduction of enteric methane. Appro. Poult. Dairy Vet. Sci., 2: 1-9.

Gerber P.J., Hristov A.N., Henderson B., Makkar H., Oh J., Lee C., Meinen R. (2013). Technical options for the mitigation of direct methane and nitrous oxide emissions from livestock: a review. Int. J. Anim. Biosci., 7: 220-234.

Gerlach K., Pries M., Tholen E., S chmithausen A.J., Büs cher W., Südekum K.H. (2018 a). Effect of condensed tannins in rations of lactating dairy cows on production variables and nitrogen use efficiency. Anim., 12: 1-9.

G e r l a c h K., Pri e s M., S ü d e k u m K.H. (2018 b). Effect of condensed tannin supplementation on in vivo nutrient digestibilities and energy values of concentrates in sheep. Small Rumin. Res., 161: 57-62.

Gessner D.K., Koch C., Romberg F.J., Winkler A., Dus el G., Herzog E., Most E., E d e r K. (2015). The effect of grape seed and grape marc meal extract on milk performance and the expression of genes of endoplasmic reticulum stress and inflammation in the liver of dairy cows in early lactation. J. Dairy Sci., 98: 8856-8868.

Getachew G., Pittroff W., Putnam D.H., Dandekar A., Goyal S., DePeters E.J. (2008). The Influence of addition of gallic acid, tannic acid, or quebracho tannins to alfalfa hay on in vitro rumen fermentation and microbial protein synthesis. Anim. Feed Sci. Technol., 140: $444-461$.

G i th i or i J.B., A th a n a s i a d o u S., T h a m s b org S.M. (2006). Use of plants in novel approaches for control of gastrointestinal helminths in livestock with emphasis on small ruminants. Vet. Parasitol., 139: 308-320.

Gómez H., Toral N., A s s e faw A., Pinto R., Jaime L. (2006). Áreas con potencial para el establecimiento de árboles forrajeros en el centro de Chiapas. Téc. Pecu. Méx., 44: 219-230.

Guglielmelli A., Calabrò S., Primi R., Carone F., Cutrignelli M.I., Tudisco R., Piccolo G., Ronchi B., Danieli P.P. (2011). In vitro fermentation patterns and methane production of sainfoin (Onobrychis viciifolia Scop.) hay with different condensed tannin contents. Grass Forage Sci., 66: 488-500.

Gunun P., Gunun N., Cherdthong A., Wanapat M., Polyorach S., Sirilaophai- 
s a n S., Wa c hir a pa k o r n C., K a n g S. (2018). In vitro rumen fermentation and methane production as affected by rambutan peel powder. J. Appl. Anim. Res., 46: 626-631.

Gx a s he ka M., L o u is T., N ing T., L y u Q.Z. (2015). An overview of tannins rich plants as alternative supplementation on ruminant animals: a review. Int. J. Agr. Res., 3: 343-349.

$\mathrm{H}$ a r tman n T. (2007). From waste products to ecochemicals: fifty years research of plant secondary metabolism. Phytochem., 68: 2831-2846.

Hatew B., Stringano E., Mueller-Harvey I., Hendriks W.H., Carbonero C.H., $\mathrm{S} \mathrm{m}$ it h L.M.J., P elli k a a n W.F. (2016). Impact of variation in structure of condensed tannins from sainfoin (Onobrychis viciifolia) on in vitro ruminal methane production and fermentation characteristics. J. Anim. Physiol. Anim. Nut., 100: 348-360.

Heckendorn F., Haring D.A., Maurer V., Senn M., Hertzberg H. (2007). Individual administration of three tanniferous forage plants to lambs artificially infected with Haemonchus contortus and Cooperia curticei. Vet. Parasitol., 146: 123-134.

Hervás G., Pérez V., Giráldez F.J., Mantecón A.R., Almar M.M., Frutos P. (2003). Intoxication of sheep with quebracho tannin extract. J. Comparative Pathol., 129: 44-54.

H o o k S.E., Wright A.D.G., M c B rid e B.W. (2010). Methanogens: methane producers of the rumen and mitigation strategies. Archaea., 2010: 50-60.

Hristov A.N., Oh J., Firkins J.L., Dijkstra J., Kebreab E., Waghorn G., Mak$\mathrm{k}$ a r H.P.S. (2013). Mitigation of methane and nitrous oxide emissions from animal operations: I. A review of enteric methane mitigation options. J. Anim. Sci., 91: 5045-5069.

Huang Q., Li u X., Zh a o G., Hu T., Wang Y. (2017). Potential and challenges of tannins as an alternative to in-feed antibiotics for farm animal production. Anim. Nutr., 9: 1-14.

H u a n g X.D., L i a n g J.B., Tan H.Y., Yah y a R., H o Y.W. (2011). Effects of Leucaena condensed tannins of differing molecular weights on in vitro $\mathrm{CH}_{4}$ production. Anim. Feed Sci. Technol., 166-167: 373-376.

I q b a 1 Z., M uft i K.A., K h a n M.N. (2002). Anthelmintic effects of condensed tannins. Int. J. Agr. Biol., 4: 438-40.

I qba 1 Z., S a rwar M., Jabbar A., A hmed S., Nis a M., S ajid M.S., Khan M.N., Muft $\mathrm{i}$ K.A., Yas e e n M. (2007). Direct and indirect anthelmintic effects of condensed tannins in sheep. Vet. Parasitol., 144: 125-131.

J a ck s on F., A than a si a d ou S., Th a m s borg S.M., Ho s k in S.O. (2006). The effects of tannin-rich plants on parasitic nematodes in ruminants. Trends Parasitol., 22: 254-261.

Jafari S., Ebrahimi M., Goh Y.M., Rajion M.A., Jahromi M.F., Al-Jumail W.S. (2019). Manipulation of rumen fermentation and methane gas production by plant secondary metabolites (saponin, tannin and essential oil) - a review. Ann. Anim. Sci., 19: 3-29.

J a m a la G.Y., Tari m bu ka I.L., M or is D., M a ha i S. (2013). The scope and potentials of fodder trees and shrubs in agroforestry. J. Agr. Vet. Sci., 5: 11-17.

J a n s s e n P.H. (2010). Influence of hydrogen on rumen methane formation and fermentation balances through microbial growth kinetics and fermentation thermodynamics. Anim. Feed Sci. Technol., 160: $1-22$.

Jayanegara A., Wina E., Soliva C.R., Marquardt S., Kreuzer M., Leiber F. (2011). Dependence of forage quality and methanogenic potential of tropical plants on their phenolic fractions as determined by principal component analysis. Anim. Feed Sci. Technol., 163: 231-243.

J a y a n g ar a A., Kreuzer M., Le iber F. (2012). Ruminal disappearance of polyunsaturated fatty acids and appearance of biohydrogenation products when incubating linseed oil with alpine forage plant species in vitro. Livest. Sci., 147: 104-112.

J a y a n e gara A., Go el G., Makkar P.S.H., B e c ker K. (2015). Divergence between purified hydrolysable and condensed tannin effects on methane emission, rumen fermentation and microbial population in vitro. Anim. Feed Sci. Technol., 209: 60-68.

Johnson K.A., Johnson D.E. (1995). Methane emissions from cattle. J. Anim. Sci., 73: 2483-2492.

J o n k e r A., Yu P. (2017). The occurrence, biosynthesis, and molecular structure of proanthocyanidins and their effects on legume forage protein precipitation, digestion and absorption in the ruminant digestive tract. Int. J. Molecul. Sci., 18: 2-23. 
J ou a y J., Morgavi D.P. (2007). Use of 'natural' products as alternatives to antibiotic feed additives in ruminant production. Anim., 1: 1443-1466.

K a m r a D.N., A g a rw a 1 N., C h a u d h a ry L.C. (2006). Inhibition of ruminal methanogenesis by tropical plants containing secondary compounds. Int. Congress Series., 1293: 156-163.

K e m p to n T.J., Murray R.M., L en g R.A. (1976). Methane production and digestibility measurements in the grey kangaroo and sheep. Aust. J. Biol. Sci., 29: 209-214.

K o n e s w a ra n G., N i e r e n berg D. (2008). Global farm animal production and global warming: impacting and mitigating climate change. Env. Health Perspectives., 116: 578-582.

Krueger W.K., Gutierrez-Bañuelos H., Carstens G.E., Min B.R., P inchak W.E., Go mez R.R., Anders on R.C., Kru e ger N.A., F orbes T.D.A. (2010). Effects of dietary tannin source on performance, feed efficiency, ruminal fermentation, and carcass and non-carcass traits in steers fed a high-grain diet. Anim. Feed Sci. Technol., 159: 1-9.

$\mathrm{K}$ u m a r K., Ch a u d a r y L., K u m a r S. (2014 a ). Exploitation of tannins to modulate rumen ecosystem and ruminants performance: a review. Ind. J. Anim. Sci., 84: 609-618.

Ku mar S., Choudhury P.K., Carro M.D., Griffith G.W., D a gar S.S., Puniy a M., C a labro S. (2014 b ). New aspects and strategies for methane mitigation from ruminants. Appl. Microbiol. Biotechnol., 98: 31-44.

K u rh e k a r J.V. (2016). Tannins - antimicrobial chemical components. Int. J. Technol. Sci., 9: 5-9.

Lamy E., Rawel H., Schweigert F.J., Silva F.C.E., Ferreira A., Costa A.R., Antu nes C., A $1 \mathrm{~m}$ e i d a A.M., C o e 1 h o A.V., S a le s - B a p t is t a E. (2011). The effect of tannins on Mediterranean ruminant ingestive behavior: the role of the oral cavity. Molecules, 16: 2766-2784.

L a s h of D., A h u j a D.R. (1990). Relative contributions of greenhouse gas emissions to global warming. Nature, 344: 529-531.

Le e S.H., Shinde P.L., Choi J.Y., Kwon I.K., Le e J.K., Pak S.I., Cho W.T., Chae B.J. (2010). Effects of tannic acid supplementation on growth performance, blood hematology, iron status and faecal microflora in weanling pigs. Livest. Sci., 131: 281-286.

L i m S.H., D a r a h I., J a in K. (2006). Antimicrobial activities of tannin extracted from rhizophora apiculata barks. J. Tropical Forest Sci., 18: 59-65.

L i u X.L., Ha o Y.Q., J in L., Xu Z.J., Mcallister T.A., Wang Y. (2013). Anti-Escherichia coli $\mathrm{O} 157: \mathrm{H} 7$ properties of purple prairie clover and sainfoin condensed tannins. Molecules, 18: 2183-2199.

L uque A., B arry T.N., M c N a b b W.C., Ke m p P.D., M c Donald M.F. (2000). The effect of grazing Lotus corniculatus during late summer-autumn on reproductive efficiency and wool production in ewes. Aust. J. Agr. Res., 51: 385-391.

Makkar H.P.S. (2003). Effects and fate of tannins in ruminant animals, adaptation to tannins, and strategies to overcome detrimental effects of feeding tannin-rich feeds. Small Rumin. Res., 49: 241-256.

Mapiye C., Chimonyo M., Dzama K., Strydom P.E., Muchenje V., Marufu M.C. (2009). Nutritional status, growth performance and carcass characteristics of nguni steers supplemented with Acacia karroo Leaf-Meal. Livest. Sci., 126: 206-214.

M a p i y e C., Ch i m o n y o M., M a r u fu M.C., D z a m a K. (2011). Utility of Acacia karroo for beef production in Southern African smallholder farming systems: a review. Anim. Feed Sci. Technol., 164: 135-146.

María J., Carrasco D., Cabral C., Redondo L.M., Daniela N., Vis o P., Colombat to D., F a rber M.D., En ri que M., M i y a k a w a F. (2017). Impact of chestnut and quebracho tannins on rumen microbiota of bovines. Bio. Med. Res. Int., 2017: 1-12.

Mc Allister T.A., Martinez T., B a e H.D., Mu ir A.D., Yanke L.J., Jones G.A. (2005). Characterization of condensed tannins purified from legume forages: chromophore production, protein precipitation, and inhibitory effects on cellulose digestion. J. Chem. Ecol., 31: 2049-2068.

Mc Michael A.J., P owles J.W., B utler C.D., U a y R. (2007). Food, livestock production, energy, climate change, and health. Lancet., 370: 1253-1263.

McNabb W.C., Waghorn G.C., Barry T.N., Shelton I.D., McNabbl W.C., Wagh or n G.C., B a rry T.N., S helt o n I.D. (1993). The effect of condensed tannins in Lotus pedunculatus on the digestion and metabolism of methionine, cystine and inorganic sulphur in sheep. British J. Nut., 70: 647-661. 
Mc S we e ne y C.S., P a $1 \mathrm{~m}$ er B., Mc Neill D.M., Krause D.O. (2001). Microbial interactions with tannins: nutritional consequences for ruminants. Anim. Feed Sci. Technol., 91: 83-93.

Mejia-Hernandez P., Salem A.Z.M., Elghandour M.M.M.Y., Cipriano-Salazar M., Cruz-Lagunas B., Ca macho L.M. (2014). Anthelmintic effects of Salix babylonica L. and Leucaena leucocephala Lam. extracts in growing lambs. Tropical Anim. Health Prod., 46: 173-178.

Menezes A.B.De., Lew is E., Donovan M.O., Neill B.F.O., Clipson N., Doyle E.M. (2011). Microbiome analysis of dairy cows fed pasture or total mixed ration diets. FEMS Microbiol. Ecol., 78: 256-265.

Min B.R., Hart S. (2003). Tannins for suppression of internal parasites. J. Anim. Sci., 81: 102-109.

Min B.R., Fernandez J.M., B arry T.N., Mc Nabb W.C., Ke mp P.D. (2001). The effect of condensed tannins in Lotus corniculatus upon reproductive efficiency and wool production in ewes during autumn. Anim. Feed Sci. Technol., 92: 185-202.

M in B.R., B arry a T.N., A t tw o od G.T., M c N a b b W.C. (2003). The effect of condensed tannins on the nutrition and health of ruminants fed fresh temperate forages: a review. Anim. Feed Sci. Technol., 106: 3-19.

M in B.R., A t two od G.T., Mc Nabb W.C., Molan A.L., B arry T.N. (2005 a). The effect of Condensed tannins from Lotus corniculatus on the proteolytic activities and growth of rumen bacteria. Anim. Feed Sci. Technol., 121: 45-58.

Min B.R., P inchak W.E., Fulford J.D., P u chala R. (2005 b). Effect of feed additives on in vitro and in vivo rumen characteristics and frothy bloat dynamics in steers grazing wheat pasture. Anim. Feed Sci. Technol., 124: 615-629.

Min B.R., Pinchak W.E., Anderson R.C., Fulford J.D., Puchala R. (2006). Effects of condensed tannins supplementation level on weight gain and in vitro and in vivo bloat precursors in steers grazing winter wheat. J. Anim. Sci., 84: 2546-2554.

M in B.R., S ol a i m a n S., S h a n ge R., E un J.S. (2014). Gastrointestinal bacterial and methanogenic archaea diversity dynamics associated with condensed tannin-containing pine bark diet in goats using 16S rDNA amplicon pyrosequencing. Int. J. Microbiol., 2014: 1-11.

Min B.R., Hernandez K., P inchak W.E., Anderson R.C., Miller J.E., Valencia E. (2015). Effects of plant tannin extracts supplementation on animal performance and gastrointestinal parasites infestation in steers grazing winter wheat. J. Anim. Sci., 5: 343-350.

Minieri S., Buccioni A., Rapaccini S., Pezzati A., Benvenuti D., Serra A., Mele M. (2014). Effect of quebracho tannin extract on soybean and linseed oil biohydrogenation by solid associated bacteria: an in vitro study. Ital. J. Anim. Sci., 13: 604-608.

Mlambo V., Sikosan a J.L.N., Mould F.L., S mith T., Owen E., Mueller-Harvey I. (2007). The effectiveness of adapted rumen fluid versus PEG to ferment tannin-containing substrates in vitro. Anim. Feed Sci. Technol., 136: 128-136.

Moate P.J., Williams S.R.O., Torok V.A., Hannah M.C., Ribaux B.E., Tavenda1 e M.H., E c k ard R.J., J a c o b s J.L., A u 1 d is t M.J., W a le s W.J. (2014). Grape marc reduces methane emissions when fed to dairy cows. J. Dairy Sci., 97: 5073-5087.

M o kn i M., A m r i M., L i m a m F., A o u a n i E. (2017). Effect of grape seed and skin supplement on milk yield and composition of dairy ewes. Tropical Anim. Health Prod., 49: 131-137.

Molan A.L., Garry C., Waghorn B.R., Warren C., Mc Nabb W.C. (2000). The Effect of Condensed tannins from seven herbages on Trichostrongylus colubriformis larval migration in vitro. Folia Parasitologica., 47: 9-44.

M o 1 a n A.L., W a g h or n G.C., M c N a b b W.C. (2002). Effect of condensed tannins on egg hatching and larval development of Trichostrongylus colubriformis in vitro. Vet. Record., 150: 65-69.

Molan A.L., D uncan A.J., B arry T.N., M c N abb W.C. (2003). Effects of condensed tannins and crude sesquiterpene lactones extracted from chicory on the motility of larvae of deer lungworm and gastrointestinal nematodes. Parasitol. Int., 52: 209-218.

M o $\mathrm{le}$ S., $\mathrm{H}$ a g e r m a n A.E., H a $\mathrm{l}$ e y T.A. (2015). Role of tannins in defending plants against ruminants: reduction in dry matter digestion. Ecology, 68: 1606-1615.

M u ell e r- H a r v e y I. (2006). Unravelling the conundrum of tannins in animal nutrition and health. J. Sci. Food Agric., 86: 1-28. 
N a u mann H.D., Te de s chi L.O., Z elle r W.E., Huntley N.F. (2017). The role of condensed tannins in ruminant animal production: advances, limitations and future directions. Revista Brasileira de Zootecnia., 46: 929-949.

$\mathrm{Ngambu}$ S., Muchenje V., Marume U. (2013). Effect of Acacia karroo supplementation on growth, ultimate ph, colour and cooking losses of meat from indigenous Xhosa lop-eared goats. Asian-Australasian J. Anim. Sci., 26: 128-133.

$\mathrm{Ng}$ u y e n T.M., B in h D.V., Ø r s k o v E.R. (2005). Effect of foliages containing condensed tannins and on gastrointestinal parasites. Anim. Feed Sci. Technol., 121: 77-87.

Niezen J.H., Charleston W.A.G., Robertson H.A., Shelton D., Waghorn G.C., G re e n R. (2002). The effect of feeding sulla (Hedysarum coronarium) or lucerne (Medicago sativa) on lamb parasite burdens and development of immunity to gastrointestinal nematodes. Vet. Parasitol., 105: 229-245.

Oliveira S.G., B erchielli T.T., Pedreira M.D.S., Primavesi O., Frighetto R., Li ma M.A. (2007). Effect of tannin levels in sorghum silage and concentrate supplementation on apparent digestibility and methane emission in beef cattle. Anim. Feed Sci. Technol., 135: 236-248.

Paengkoum P., Phonmun T., Liang J.B., Huang X.D., Tan H.Y., Jahromi M.F. (2015). Molecular weight, protein binding affinity and methane mitigation of condensed tannins from mangosteen-peel (Garcinia mangostana L). Asian-Australas. J. Anim. Sci., 28: 1442-1448.

Paolin i V., B erge a d J.P., Gris e z C., Prevot F., D or chi es P., Hos te H. (2003). Effects of condensed tannins on goats experimentally infected with Haemonchus contortus. Vet. Parasitol., 113: 253-261.

Pa ol in i V., F a rge F.D.L., Prevot F., D orchies P., Hos te H. (2005). Effects of the repeated distribution of sainfoin hay on the resistance and the resilience of goats naturally infected with gastrointestinal nematodes. Vet. Parasitol., 127: 277-283.

Papanastas is V.P., Yiakoulaki M.D., Dec andia M., Dini-Papanastasi O. (2008). Integrating woody species into livestock feeding in the Mediterranean areas of Europe. Anim. Feed Sci. Technol., 140: 1-17.

P a thak A.K., N a ray a n D., B an erje e P.S., P a t t a n a i k A.K., S har ma K. (2013). Influence of dietary supplementation of condensed tannins through leaf meal mixture on intake, nutrient utilization and performance of Haemonchus contortus infected sheep. Asian-Australas. J. Anim. Sci., 26: $1446-1458$.

Pathak A.K., Narayan D., Pattanaik A.K., Chaturvedi V.B., Sharma K. (2017). Effect of condensed tannins from Ficus infectoria and Psidium guajava leaf meal mixture on nutrient metabolism, methane emission and performance of lambs. Asian-Australas. J. Anim. Sci., 30: $1702-1710$.

P at r a A.K. (2010). Meta-analyses of effects of phytochemicals on digestibility and rumen fermentation characteristics associated with methanogenesis. J. Sci. Food Agric., 90: 2700-2708.

P a tra A.K., S a x e n a J. (2011). Exploitation of dietary tannins to improve rumen metabolism and ruminant nutrition. J. Sci. Food Agric., 91: 24-37.

P at r a A.K., Yu Z. (2012). Effects of essential oils on methane production and fermentation by, and abundance and diversity of rumen microbial populations. Appl. Environ. Microbiol., 78: 4271-4280.

Patra A.K., Yu Z. (2013). Effective reduction of enteric methane production by a combination of nitrate and saponin without adverse effect on feed degradability, fermentation, or bacterial and archaeal communities of the rumen. Bioresour.Technol., 148: 352-360.

Patra P.K., Sa eki T., Dlugokencky E.J., I shijima K., Umezawa T., Ito A., A oki S. (2016). Regional methane emission estimation based on observed atmospheric concentrations. J. Meteorol. Society Japan. Ser., 94: 91-113.

Pellikaan W.F., Stringano E., Leenaars J., Bongers D.J.G.M., Laar-van Schuppen S.V., Plant J., Mueller-Harvey I. (2011). Evaluating the effects of tannins on the extent and rate of in vitro measured gas and methane production using the automated pressure evaluation system (APES). Anim. Feed Sci. Technol., 167: 377-390.

P e t e k M., D i k m e n S. (2006). The effects of prestorage incubation and length of storage of broiler breeder eggs on hatchability and subsequent growth performance of progeny. Czech J. Anim. Sci., 51: 73-77. 
P i l u z z a G., S u las L., B ull it t a S. (2013). Tannins in forage plants and their role in animal husbandry and environmental sustainability: a review. Grass Forage Sci., 69: 32-48.

Pineiro-Vázquez A.T., Canul-Solis J.R., Alayon-Gamboa J.A., Chay-Canul A.J., Ayala-Burgos A.J., Aguilar-Perez C.F., Solorio-Sanchez F.J., KuVer a J.C. (2015). Potential of condensed tannins for the reduction of emissions of enteric methane and their effect on ruminant productivity. Arch. Med. Vet., 47: 263-272.

Pinski B., Günal M., AbuGhazaleh A.A. (2015). The effects of essential oil and condensed tannin on fermentation. Anim. Prod. Sci., 56: 266-272.

Priolo A., Wagh orn W.C., Lanza M., B i ondi L., P enn is i P. (2000). Polyethylene glycol as a means for reducing the impact of condensed tannins in carob pulp: effects on lamb growth performance and meat quality. J. Anim. Sci., 78: 810-816.

Pri olo A., B ella M., Lanza M., Galo faro V., B i ond i L., B a rb a gallo D., S a le m H.B., P e n n is i P. (2005). Carcass and meat quality of lambs fed fresh sulla (Hedysarum coronarium L.) with or without polyethylene glycol or concentrate. Small Rumin. Res., 59: 281-288.

Puchala R., Min B.R., G o e t s ch A.L., S a hlu T. (2005). The effect of a condensed tannin-containing forage on methane emission by goats. J. Anim. Sci., 83: 182-186.

R a mír e z - R e s tre p o C.A., B a r r y T.N. (2005). Alternative temperate forages containing secondary compounds for improving sustainable productivity in grazing ruminants. Anim. Feed Sci. Technol., 120: 179-201.

Reed J.D., Soller H., Wo odward A. (1990). Fodder tree and straw diets for sheep: intake, growth, digestibility and the effects of phenolics on nitrogen utilisation. Anim. Feed Sci. Technol., 30: 39-50.

Rira M., Chentli A., B oufenera S., Bousseboua H. (2015). Effects of plants containing secondary metabolites on ruminal methanogenesis of sheep in vitro. Energy Procedia., 74: $15-24$

Rivera-Mendez C., Plascencia A., Torrentera N., Zinn R.A. (2016). Effect of level and source of supplemental tannin on growth performance of steers during the late finishing phase. J. Appl. Anim. Res., 45: 199-203.

R o chfort S., P a rker A.J., D un s h e a F.R. (2008). Plant bioactives for ruminant health and productivity. Phytochemistry, 69: 299-322.

S a l e m H.B. (2010). Nutritional management to improve sheep and goat performances in semiarid regions. Revista Brasileira de Zootecnia., 39: 337-347.

S a le m H.B., N e f z a o u i A., M a k k a r H.P.S., H o c h le f H., S a le m I.B., S a l e m L.B. (2005). Effect of early experience and adaptation period on voluntary intake, digestion, and growth in barbarine lambs given tannin-containing (Acacia cyanophylla Lindl. foliage) or tannin-free (oaten hay) diets. Anim. Feed Sci. Technol., 122: 59-77.

S a m in athan M., S i e C.C., Gan H.M., A bdullah N., Wong C.M.V.L., Ho Y.W. (2016). Effects of condensed tannin fractions of different molecular weights on population and diversity of bovine rumen methanogenic archaea in vitro, as determined by high-throughput sequencing. Anim. Feed Sci. Technol., 216: 146-160.

S c h of i e ld P., M bu g u a D.M., P ell A.N. (2001). Analysis of condensed tannins: a review. Anim. Feed Sci. Technol., 91: 21-40.

Śliwiński B.J., Soliva C.R., Machmüller A., Kreuzer M. (2002). Efficacy of plant extracts rich in secondary constituents to modify rumen fermentation. Anim. Feed Sci. Technol., 101: 101-114.

S mith A.H., M a cki e R.I. (2004). Effect of condensed tannins on bacterial diversity and metabolic activity in the rat gastrointestinal tract. Appl. Envir. Microbiol., 70: 1104-1115.

S mith A.H., Z o etendal E., Mackie R.I. (2005). Bacterial mechanisms to overcome inhibitory effects of dietary tannins. Microbial Ecology, 50: 197-205.

Soltan Y.A., Mors y A.S., S alla m S.M.A., L ouvandini H., A bdalla A.L. (2012). Comparative in vitro evaluation of forage legumes (prosopis, acacia, atriplex, and leucaena) on ruminal fermentation and methanogenesis. J. Anim. Feed Sci., 21: 753-766.

Soltan Y.A., Morsy A.S., S allam S.M.A., Lucas R.C., Louvandini H., Kreuzer M., A b d a 11 a A.L. (2013). Contribution of condensed tannins and mimosine to the methane mitigation caused by feeding Leucaena leucocephala. Arch. Anim. Nutr., 67: 169-184. 
Tavendale M.H., Me a g her L.P., P a checo D., Wa lker N., A t tw ood G.T., S iv a ku ma r a n S. (2005). Methane production from in vitro rumen incubations with Lotus pedunculatus and Medicago sativa, and effects of extractable condensed tannin fractions on methanogenesis. Anim. Feed Sci. Technol., 124: 403-419.

Theodoridou K., Aufrère J., Andueza D., Pourrat J., Le Morvan A., Stringano E., Mueller-Harvey I., B a umont R. (2010). Effects of condensed tannins in fresh sainfoin (Onobrychis viciifolia) on in vivo and in situ digestion in sheep. Anim. Feed Sci. Technol., 160: 23-38.

T h o r n t o n P.K., G e r b e r P.J. (2010). Climate change and the growth of the livestock sector in developing countries. Mitigation adaptation strategies for global change, 15: 169-184.

T i e mann T.T., L a s c ano C.E., We t t s t e in H.R., May e r A.C., Kreuzer M., Hess H.D. (2008). Effect of the tropical tannin-rich shrub legumes Calliandra calothyrsus and Flemingia macrophylla on methane emission and nitrogen and energy balance in growing lambs. Int. J. Anim. Biosci., 2: 790-799.

Tzamaloukas O., A thanasiadou S., Kyriazakis I., Jackson F., Coop R.L. (2005). The consequences of short-term grazing of bioactive forages on established adult and incoming larvae populations of Teladorsagia circumcincta in lambs. Int. J. Parasitol., 35: 329-335.

Vas t a V., Nudda A., Cann as A., L an za M., Pri o lo A. (2008). Alternative feed resources and their effects on the quality of meat and milk from small ruminants. Anim. Feed Sci. Technol., 147: $223-246$.

Wa g h or n G. (2008). Beneficial and detrimental effects of dietary condensed tannins for sustainable sheep and goat production-progress and challenges. Anim. Feed Sci. Technol., 147: 116-139.

Wa ghorn G.C., Tavendale M.H., Woodfie ld D.R. (2002). Methanogenesis from forages fed to sheep. Proceedings of the New Zealand Grassland Association, 64: 167-71.

Wall a c e R.J., McEw an N.R., Mc Int os h F.M., Teferedegne B., N ew bold C.J. (2002). Natural products as manipulators of rumen fermentation. Asian-Australasian J. Anim. Sci., 15: 1458-1468.

W a n a p a t M. (2003). Manipulation of cassava cultivation and utilization to improve protein to energy biomass for livestock feeding in the tropics. Asian-Australas. J. Anim. Sci., 16: 463-472.

Wan a pat M., Chan thakh oun V., Phes a t cha K., Kang S. (2014). Influence of mangosteen peel powder as a source of plant secondary compounds on rumen microorganisms, volatile fatty acids, methane and microbial protein synthesis in swamp buffaloes. Livest. Sci., 162: 126-133.

Wan a pat M., Cherdthong A., Phes a t cha K., K ang S. (2015). Dietary sources and their effects on animal production and environmental sustainability. Anim. Nutr., 1: 96-103.

Wang Y., X u Z., B a c h S.J., M c A 11 i s t e r T.A. (2009). Sensitivity of Escherichia coli to seaweed (Ascophyllum nodosum) phlorotannins and terrestrial tannins. Asian-Australas. J. Anim. Sci., 22: 238-245.

Wang Y., Ma j a k W., M c A 11 is t e r T.A. (2012). Frothy bloat in ruminants: cause, occurrence, and mitigation strategies. Anim. Feed Sci. Technol., 172: 103-114.

Wang Y., Jin L., Ominski K.H., He M., Xu Z., Krause D.O., Acharya S.N. (2013). Screening of condensed tannins from Canadian prairie forages for anti-Escherichia coli O157: H7 with an emphasis on purple prairie clover (Dalea purpurea Vent). J. Food Protection, 76: 560-567.

Wang Y., Mc A 11 ister T.A., A charya S. (2015). Condensed tannins in sainfoin: composition, concentration, and effects on nutritive and feeding value of sainfoin forage. Crop Sci., 55: 13-22.

Williams C.M., Eun J.S., MacAdam J.W., Young A.J., Fellner V., Min B.R. (2011). Effects of forage legumes containing condensed tannins on methane and ammonia production in continuous cultures of mixed ruminal microorganisms. Anim. Feed Sci. Technol., 167: 364-372.

Wischer G., Boguhn J., Steingass H., Schollenberger M., Rodehutscord M. (2013). Effects of different tannin-rich extracts and rapeseed tannin monomers on methane formation and microbial protein synthesis in vitro. Animal, 7: 1-10.

Wo odwa rd S.L., Wa gh or n G.C., Uly at t M.J., L a s s e y K.R. (2001). Early indications that feeding lotus will reduce methane emissions from ruminants. Proceedings of the New Zealand Society of Animal Production., 61: 23-26.

Yang C., Chow dhury M.A.C., Hu o Y., Gong J. (2015). Phytogenic compounds as alternatives to in-feed antibiotics: potentials and challenges in application. Pathogens, 4: 137-156. 
Yis ehak K., B e cker A., Rothman J.M., Dierenfeld E.S., Marescau B., Bosch G., Hendriks W., J a n s s e n s G.P.J. (2012). Amino acid profile of salivary proteins and plasmatic trace mineral response to dietary condensed tannins in free-ranging zebu cattle (Bos indicus) as a marker of habitat degradation. Livest. Sci., 144: 275-280.

Z e n e b e S., F e y e r a T., A s s e fa S. (2017). In vitro anthelmintic activity of crude extracts of aerial parts of Cissus quadrangularis L. and leaves of Schinus molle L. against Haemonchus contortus. BioMed. Res. Int., 2017: 1-7.

Received: 12 VIII 2019

Accepted: 13 XII 2019 